\title{
Geochemical and isotopic evidence for upward flow of saline fluid to the Mississippi River Valley alluvial aquifer, southeastern Arkansas, USA
}

\author{
Daniel Larsen ${ }^{1} \cdot$ Justin Paul ${ }^{2} \cdot$ Randy Cox ${ }^{1}$ \\ Received: 20 June 2020 / Accepted: 12 February 2021 / Published online: 31 March 2021 \\ (C) The Author(s) 2021, corrected publication 2021
}

\begin{abstract}
Groundwater from the Quaternary Mississippi River Valley Alluvial (MRVA) aquifer in southeastern Arkansas (SE AR), USA, has higher salinity compared to other MRVA groundwater. Previous studies have argued for infiltration of evaporated soil water as a primary source for the elevated salinity, although seepage from local rivers and deep groundwater sources also have been considered. Geochemical and isotope data from irrigation, public supply, and industrial wells, as well as subsurface geologic data, are used to demonstrate that upward flow of saline water along regional faults is the primary source of salinity in MRVA aquifer groundwater in SE AR. Sodium, chloride $\left(\mathrm{Cl}^{-}\right)$and bromide $\left(\mathrm{Br}^{-}\right)$concentrations illustrate mixing relationships between MRVA aquifer groundwater and Jurassic Smackover Formation brine, with mixing percentages of $<1 \%$ Smackover brine being the source of anomalously high $\mathrm{Cl}^{-}, \mathrm{Br}^{-}$, and other ions in MRVA groundwater with elevated salinity. Stable oxygen and hydrogen isotope data suggest substantial mixing of Paleogene Wilcox Formation water with that of the MRVA aquifer groundwater and varying degrees of evaporative concentration. Radiocarbon and helium isotope data argue for contributions of chloride-rich, pre-modern and relatively fresh modern water for recharge to the MRVA aquifer. Chloride concentration in MRVA aquifer waters closely follows the spatial distribution of earthquake-induced liquefaction features and known or suspected geologic faults in SE AR and northeastern Louisiana. A conceptual model is developed where deepseated basinal fluids in overpressured reservoirs migrate upward along faults during and following Holocene earthquakes into the overlying MRVA over 100s to 1,000 s of years
\end{abstract}

Keywords Hydrochemistry $\cdot$ Brine $\cdot$ Salinization $\cdot$ USA $\cdot$ Fractured rocks

\section{Introduction}

Vertical upward migration of groundwater is known to affect water quality in near-surface aquifers. The conditions leading to upward migration vary, but most commonly stem from flow along preferential pathways from underlying rock units at elevated pore pressure (Carrillo-Rivera et al. 1996; Mehta et al. 2000; Frumkin and Gvirtzman 2006; Petitta et al. 2011), thermohaline convection (Evans et al. 1991; Magri et al. 2009), groundwater pumping in shallow aquifers (Howard

Daniel Larsen

dlarsen@memphis.edu

1 Department of Earth Sciences, University of Memphis, Memphis, TN 38152, USA

2 Pittsburgh, USA and Mullings 1996; Cherry 2019), or cross-formational or up-dip flow (Ma et al. 2005). Changes in water chemistry due to upward groundwater flow or release of solutes due to dilation may also occur along faults during earthquakes (Favara et al. 2001; Claesson et al. 2004; Malakootian and Nouri 2010; Woith et al. 2013; Skelton et al. 2014; Rosen et al. 2018). Hydrologic conditions leading to upward migration of saline water into shallow aquifers, especially those utilized extensively for agricultural or industrial water supply, are not well understood. In particular, the degree to which extensive pumping versus natural processes cause upward fluid migration can be difficult to assess.

Groundwater pumped from the Mississippi River Valley Alluvial (MRVA) aquifer is used for irrigation throughout the south-central United States, with average annual pumping of 34 billion L/day (Clark et al. 2011). Water quality problems are generally mild in the aquifer, especially in northeastern Arkansas, western Tennessee, and southeastern Missouri 
(Waldron et al. 2011; Kingsbury et al. 2015). However, elevated salinity (as indicated by $>100 \mathrm{mg} \mathrm{mg} / \mathrm{L}$ chloride) has been observed in the MRVA aquifer in southeastern Arkansas (SE AR) since the 1950's (Onellion and Criner 1955; Bedinger and Reed 1961; Kresse and Clark 2008). Sources for the elevated salinity have commonly been attributed to upward flow from underlying formations (Onellion and Criner 1955; Broom and Reed 1973; Fitzpatrick 1985; Kresse and Clark 2008), interactions with infiltrated river water (Bedinger and Jeffery 1964; Kresse and Fazio 2002), and infiltrated soil water that had been evaporatively concentrated (Kresse and Fazio 2002; Kresse and Clark 2008). Most recently, spatial analysis of groundwater quality data in the MRVA aquifer, Holocene earthquake liquefaction features, and surficial deposits in SE AR established a strong correspondence between salinity in the MRVA aquifer and liquefaction features (Paul et al. 2017), suggesting a prominent role of upward migration of deep subsurface fluids along faults.

In the present study, chemical and isotopic hydrologic tracers from irrigation wells screened in the MRVA aquifer (Fig. 1), and limited sampling of wells screened in the Middle and Lower Claiborne aquifers are used to evaluate the role of upward migration of deep subsurface fluids versus shallow surface sources in development of elevated salinity in the MRVA aquifer in SE AR. Previous studies have generally taken a qualitative or graphical approach to assessing the contributions of various salinity sources, using little isotope or trace element data. Statistical analysis of existing water chemistry data was used to identify a limited number of wells for sampling major and trace element geochemistry, stable hydrogen, carbon and oxygen isotopes $\left(\delta^{2} \mathrm{H}, \delta^{13} \mathrm{C}\right.$, and $\left.\delta^{18} \mathrm{O}\right)$, tritium $\left({ }^{3} \mathrm{H}\right)$, helium isotopes $\left({ }^{3} \mathrm{He} /{ }^{4} \mathrm{He}\right)$, noble gases and carbon$14\left({ }^{14} \mathrm{C}\right)$. These data are used to evaluate the residence time, chemical and isotopic mixing relationships, and the geochemical evolution of shallow groundwater with potential mixing components. A hydrogeologic conceptual model for the distribution of saline groundwater in the MRVA aquifer in SE $\mathrm{AR}$ is presented that illustrates mechanisms that may be important in other regions, especially where both tectonic and anthropogenic processes may impact shallow groundwater quality.

\section{Geologic and hydrologic background}

Southeastern Arkansas is in the south-central portion of the Mississippi embayment (ME). The structural basin of the ME contains more than $1.5 \mathrm{~km}(\mathrm{~km})$ of Mesozoic and Cenozoic sediments overlying metamorphosed sedimentary rocks of the Paleozoic Ouachita fold-thrust belt (Cushing et al. 1964; Cox and Van Arsdale 2002). The lower Mesozoic strata unconformably overlie the Paleozoic rocks and comprise Upper Triassic through Upper Jurassic continental, evaporative, and shallow marine deposits associated with rifting and development of the Gulf of Mexico (Cushing et al. 1964; Dickinson 1968; Harry and Londono 2004; Cox et al. 2013). The upper Mesozoic and Cenozoic strata unconformably overlie the lower Mesozoic sediments and comprise Cretaceous through Neogene marine and fluvial deposits of the ME structural basin (Cushing et al. 1964; Cox et al. 2013), which is attributed to the ME passing over the Bermuda hotspot (Cox and Van Arsdale 2002). Pleistocene and Holocene sediments include fluvial and lacustrine deposits of the Mississippi River and its tributaries in the lower Mississippi River alluvial valley (Saucier 1994).

Recent geophysical and structural studies in SE AR provide evidence for several ancient and active faults that offset Jurassic through Pleistocene and Holocene deposits (Cox et al. 2006, 2010, 2012, 2013; Hao et al. 2015). Sand-blow fields observed throughout SE AR are interpreted to record liquefaction from local earthquakes during the Holocene (Cox et al. 2006, 2010). Pleistocene and Holocene deposits are offset along the Saline River fault zone in southern Arkansas (Cox et al. 2013), providing evidence for seismicity in the southern ME along the basement Alabama-Oklahoma transform zone.

Most recently, Hao et al. (2015) imaged the Arkansas River Fault Zone and two unnamed faults associated with the Monroe Uplift along the Mississippi River, the latter two faults show evidence for Quaternary movement.

The Cretaceous through Quaternary sediments comprise a system of aquifers and confining units in the ME (Fig. 2; Hart et al. 2008). Freshwater is produced for municipal and industrial uses extensively from the Eocene Sparta Sand (Middle Claiborne aquifer; Kingsbury et al. 2015), but water quality in the deeper Eocene Carrizo Sand (Lower Claiborne aquifer) and Paleocene Wilcox Formation is poor, with moderate to high total dissolved solids (Waldron et al. 2011).

\section{Hydrogeology of the MRVA aquifer in SE AR}

The MRVA aquifer is present beneath over $50,000 \mathrm{~km}^{2}\left(\mathrm{~km}^{2}\right)$ in parts of Missouri, Kentucky, Tennessee, Louisiana, and SE $\mathrm{AR}$, with thicknesses ranging from 15 to $45 \mathrm{~m}$ (m). The aquifer materials include Quaternary sand and gravel deposited by the Mississippi River and its tributaries (Saucier 1994). The MRVA aquifer is capped by the Mississippi River Valley confining unit, which is composed of 3-15 m of Quaternary clay, silt, and fine-grained sand deposited in low energy environments of the Mississippi River and its tributaries (Ackerman 1996; Kresse et al. 2014). Relatively rapid natural and artificial recharge occurs over the aquifer's geographic extent, except where the confining unit limits recharge (Kresse and Fazio 2002; Kresse et al. 2014). The aquifer is also in hydraulic connection with the Mississippi River and other regional rivers (Ackerman 1996). 


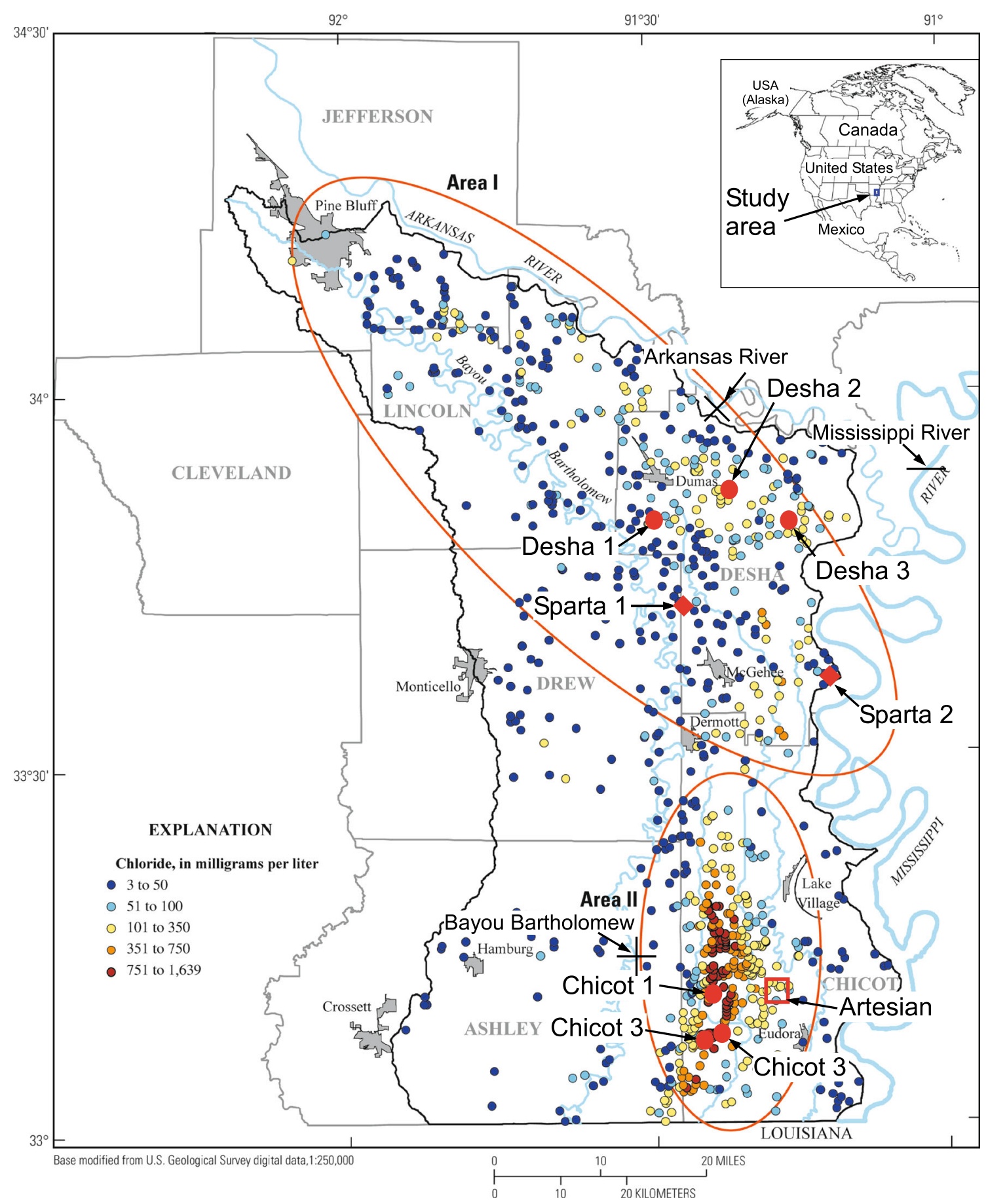

Fig. 1 Location of sampling sites in Chicot and Desha counties, Arkansas, overlain on the distribution of chloride concentrations in groundwater samples from irrigation wells screened in the MRVA aquifer (modified from Kresse and Clark 2008). Surface-water sites

The MRVA aquifer is used primarily for irrigation water and had the third largest irrigation water production in the US with a total economic impact of nearly 10 billion dollars per year in 2017 (Alhassan et al. 2019). The MRVA aquifer has an average hydraulic conductivity of $60 \mathrm{~m}$ per day (m/day) (Ackerman 1996) and a saturated thickness in excess of $15 \mathrm{~m}$
(USGS data) are shown for the Arkansas River, Bayou Bartholomew, and Mississippi River. Red markers indicate groundwater and and black markers signify surface water. Inset shows location of study area in North America

in most places, but water levels are continuing to decline over the region (Kresse et al. 2014). Over 4700 irrigation wells in the MRVA aquifer commonly produce over 1,800 L/min and upwards of 7,500 L/min in some instances (Czarnecki 2010) to irrigate fields of corn, cotton, rice, and soybeans (Kresse et al. 2014). 
Fig. 2 Hydrostratigraphic column of southeastern Arkansas (SE AR)

\begin{tabular}{|c|c|c|c|c|c|}
\hline \multirow[t]{2}{*}{ Era } & \multirow[t]{2}{*}{ Period } & \multirow[t]{2}{*}{ Epoch } & \multicolumn{3}{|c|}{ Southeastern Arkansas } \\
\hline & & & Group & Formation & Hydrostratigraphic unit \\
\hline \multirow{12}{*}{ Cenozoic } & \multirow{2}{*}{ Quaternary } & Holocene & & $\begin{array}{c}\text { Mississippi River } \\
\text { Valley Allyvium (MRVA) }\end{array}$ & MRVA \\
\hline & & Pleistocene & & Fluvial-terrace & \multirow{2}{*}{$\begin{array}{c}\text { Fluvial-terrace } \\
\text { aquifer }\end{array}$} \\
\hline & Neogene & Pliocene & & Upland Complex & \\
\hline & \multirow{9}{*}{ Paleogene } & \multirow{6}{*}{ Eocene } & Jackson & $\begin{array}{l}\text { Jackson } \\
\text { Formation }\end{array}$ & $\begin{array}{c}\text { Jackson } \\
\text { confining unit }\end{array}$ \\
\hline & & & \multirow{5}{*}{ Claiborne } & Cockfield Formation & Upper Claiborne aquifer \\
\hline & & & & Cook Mountain Formation & $\begin{array}{c}\text { Middle Claiborne confining } \\
\text { unit } \\
\end{array}$ \\
\hline & & & & Sparta Sand & Middle Claiborne aquifer \\
\hline & & & & $\begin{array}{l}\text { Cane River } \\
\text { Formation }\end{array}$ & $\begin{array}{l}\text { Lower Claiborne } \\
\text { confining unit }\end{array}$ \\
\hline & & & & Carrizzo Sand & Lower Claiborne aquifer \\
\hline & & \multirow[b]{3}{*}{ Paleo } & \multirow[t]{2}{*}{ Wilcox } & \multirow[t]{2}{*}{ Wilcox Formation } & $\begin{array}{l}\text { Middle Wilcox } \\
\text { confining unit }\end{array}$ \\
\hline & & & & & Lower Wilcox aquifer \\
\hline & & & Midway & $\begin{array}{c}\text { Porters Creek Formation } \\
\text { Clayton Formation }\end{array}$ & $\begin{array}{c}\text { Midway } \\
\text { confining unit }\end{array}$ \\
\hline
\end{tabular}

Overall, the quality of groundwater from the MRVA aquifer throughout much of the ME is good (Kresse et al. 2014). The groundwater has a mixed cation-bicarbonate composition (Waldron et al. 2011), but elevated concentrations of hardness, iron, and manganese commonly limit domestic and municipal water supply use (Kresse et al. 2014). Anomalously high chloride concentrations in the MRVA aquifer were first discovered during the late 1940's during a period of increased demand for irrigation water (Kresse and Clark 2008). Onellion and Criner (1955) measured chloride concentrations of MRVA aquifer groundwater from Chicot County in excess of 1,400 mg/L, whereas Bedinger and Reed (1961) noted a north-south trending band of elevated (>50 mg/L) chloride concentrations in Desha County with concentrations in some wells as high as $182 \mathrm{mg} / \mathrm{L}$. Kresse and Clark (2008) showed anomalously high chloride concentrations in two areas (Fig. 1). "Area I" is a diffuse, northwest-southeast trending zone of moderately elevated chloride concentrations, with the highest concentrations in Desha County (Kresse and Clark 2008). Groundwater from 203 irrigation wells in Desha County yielded an average chloride content of $86 \mathrm{mg} / \mathrm{L}$ and a maximum of $361 \mathrm{mg} / \mathrm{L}$ (Kresse and Clark 2008). "Area II" is a narrow, north-south trending zone of anomalously chloriderich waters in Chicot County. The chloride anomaly is more pronounced in area II compared to area I, where a $225 \mathrm{~km}^{2}$ area produces irrigation water with chloride contents in excess of $200 \mathrm{mg} / \mathrm{L}$, with some as high as $1,639 \mathrm{mg} / \mathrm{L}$ (Kresse and Clark 2008). This is significant considering the Arkansas Cooperative Extension Service recommended limit of chloride concentration in rice irrigation water is $100 \mathrm{mg} / \mathrm{L}$ (Tacker et al. 1994).

The origin of the anomalously high chloride concentrations in groundwater in SE AR remains unclear. Previous authors have suggested the chloride anomalies in Chicot County are due to the upward flow of groundwater from deeper formations (Onellion and Criner 1955; Broom and Reed 1973; Fitzpatrick 1985; Huff and Bonck 1993; Kresse and Clark 2008). Fitzpatrick (1985) suggested the chloride anomalies in Desha County were also due to upward flow of groundwater from deeper aquifers, whereas other authors have argued the chloride anomalies are due to aquifer transmissivity (Broom and Reed 1973) or evaporative processes in surface soils (Kresse and Clark 2008). Bedinger and Reed (1961) and Fitzpatrick (1985) also noted some chloride anomalies in Desha County were proximal to the Arkansas River. Paul et al. (2017) showed strong spatial correlation between earthquakeinduced liquefaction sand-blows (Cox et al. 2004; Cox et al. 2006) and chloride anomalies in the MRVA aquifer in Desha County (Kresse and Clark 2008), suggesting the groundwater anomalies are related to tectonic processes.

\section{Application of hydrologic tracers in the MRVA aquifer in SE AR}

Isotopic and chemical hydrologic tracer data were obtained from the MRVA aquifer in select wells to test hypotheses regarding the source of elevated chloride in SE AR. The presence of tritium $\left({ }^{3} \mathrm{H}\right)$ and tritiogenic ${ }^{3} \mathrm{He}$ above background concentrations indicate the presence of modern water ( $<60$ years old), thus, distinguishing near-surface recharge sources from older, deeper sources (e.g., Zhong et al. 2019; Palcsu et al. 2017; McMahon et al. 2011; Cook and Bohlke 2000). Helium-4 $\left({ }^{4} \mathrm{He}\right)$ concentration and ${ }^{3} \mathrm{He} /{ }^{4} \mathrm{He}$ are useful for identifying geologically older groundwater of deep crustal origin (e.g., Vautour et al. 2015; Gardner and Heilweil 2014; Solomon 2000). Carbon-14 $\left({ }^{14} \mathrm{C}\right)$ can provide age constraints for groundwater that is hundreds to tens of thousands of years old (Cook and Dogramaci 2019; Kalin 2000), clarifying residence times of aquifer storage. Stable oxygen and hydrogen isotope ratio tracers are sensitive to evaporation and water- 
rock interactions (Coplen et al. 2000) and provide information regarding specific recharge sources, especially those from infiltrated stream or soil water (e.g., Kendall and Coplen 2001). Noble gases indicate recharge processes by providing recharge temperatures and excess gas contents (Mazor 1976; Aeschbach-Hertig et al. 2000). Elevated trace element concentrations are commonly associated with specific groundwater sources or hydrochemical processes and provide useful tracers where unique end-member compositions can be defined (e.g., deep basin brines; Carpenter and Trout 1978). None of these tracers by themselves provides definitive data for testing the proposed sources of chloride, but as an ensemble the data permit elimination or support for specific hypotheses.

\section{Methods}

\section{Well selection}

The well selection strategy was designed to sample groundwater from wells screened in the MRVA aquifer with varying chloride concentrations and beneath different soil types. For comparison, two wells screened in the Middle Claiborne aquifer and one flowing artesian well screened in the Lower Claiborne aquifer were also sampled. Factor analysis was performed on existing groundwater quality data from the United States Geological Survey (USGS) database (Kresse and Clark 2008), which are shown in Fig. 1, and additional data (T. Kresse, US Geological Survey, personal communication, Kresse et al. 2014) to identify a limited number of wells for sampling (e.g., Kreamer et al. 1996). Factor analysis is a statistical method for identifying systematic variations in a data set by which each member of the data set is related to a series of eigenvectors, in this case based on chemical data. The eigenvectors represent trends in the variance of the chemical data allowing specific groups to be identified based on chloride content or salinity.

Identification of wells appropriate for sampling further required contacting individual farmers for permission to sample the wells. In many cases, the wells identified for sampling by the factor analysis were no longer operational and proximal substitutes were found. Because of the sensitivity of farmers to revealing the salinity of groundwater on their property, individual sampled wells are indicated only approximately in Fig. 1. Information about the well depth and construction was obtained from the farmers or municipalities. The depth of the top of screen in the flowing artesian well was estimated using the water temperature, measured heat flow in the study area (Blackwell et al. 2011), thermal conductivity values of geologic materials (Eppelbaum et al. 2014), and an estimation of sand and clay content in geophysical borehole logs from the study area (Hart et al. 2008).

\section{Sampling procedures}

MRVA aquifer groundwater samples were collected from six irrigation wells in Chicot and Desha Counties, Arkansas (Table 1). The irrigation wells were sampled in July 2013 after being extensively pumped during the spring and early summer to obtain groundwater samples from the MRVA aquifer under stressed conditions. Samples were collected by connecting into the air-release pipe on top the distribution outflow pipe of the well assembly with the use of a $5-\mathrm{cm}(\mathrm{cm})(2-$ in.) steel couple stepped-down with PVC couples to a $1.3 \mathrm{~cm}(0.5$ in.) brass barb. Teflon tape was applied to all couple threads to ensure an air-tight seal. Teflon tubing $(1.3 \mathrm{~cm}$ inner diameter) was attached to the barb through which water flowed into a YSI 6600 flow-through cell and discharged through a supply line for sample collection. Backpressure was applied to the wells if bubbles were observed in the sampling string.

Middle Claiborne aquifer groundwater samples were collected from two municipal supply wells in Desha County. Samples were collected by connecting into a tap on the outflow pipe from the pump where water quality samples are collected. Teflon tubing ( $1.3 \mathrm{~cm}$ inner diameter) was attached to the tap through which water flowed into the YSI flowthrough cell and discharged through a supply line for sample collection. A Lower Claiborne aquifer groundwater sample was obtained from a flowing artesian well at an abandoned fish farm in Chicot County. The well was inaccessible, but a sample was collected by placing $1.3-\mathrm{cm}$ Teflon tubing into the throat of the discharge pipe from the well. The Teflon tubing was connected to a YSI 6600 flow-through cell through which water would flow for sample collection.

Field measurements were made with a YSI 6600 multiprobe sonde and included dissolved oxygen (DO), oxidation-reduction potential (ORP), $\mathrm{pH}$, specific conductance (SC), and water temperature $\left({ }^{\circ} \mathrm{C}\right)$. Samples were collected after the field measurements had stabilized. Field alkalinity was performed using a Hach titration kit with 1.6 normal (N) sulfuric acid into $25 \mathrm{ml}$ of sample water with bromcresol green-methyl red indicator. Total gas pressure (TGP) was measured using a calibrated probe and meter. Filtered and unpreserved samples were collected in $125-\mathrm{ml}$ plastic bottles for anion and stable isotope analysis. Cation and trace metal samples were field-filtered and acidified with $1 \mathrm{ml}$ of $2 \mathrm{~N}$ nitric acid and collected in $125-\mathrm{ml}$ plastic bottles. Field duplicate and blank samples were collected for anion, cation, and trace metal analyses to evaluate sampling bias and lab analysis quality. Tritium samples were obtained in 1-L amber glass bottles by submerging the bottle in a metal bucket to avoid contact with the atmosphere and eliminate headspace. Carbon-14 samples were collected in a similar fashion in $125-\mathrm{ml}$ glass bottles, except that $100 \mathrm{ml}$ of mercury chloride preservative was added to the stopper volume and Apiezon grease was applied to the stopper to effectively seal the bottle. 
Table 1 Well and field data

\begin{tabular}{|c|c|c|c|c|c|c|c|c|c|c|c|}
\hline $\begin{array}{l}\text { Well } \\
\text { name }\end{array}$ & $\begin{array}{l}\text { Screen depth } \\
(\mathrm{m} \text { bgs })\end{array}$ & $\begin{array}{l}\text { Surface soil } \\
\text { (Saucier 1994) }\end{array}$ & $\begin{array}{l}\text { Sample } \\
\text { date }\end{array}$ & $\begin{array}{l}\text { Water } \\
\text { temp. }\left({ }^{\circ} \mathrm{C}\right)\end{array}$ & $\begin{array}{l}\mathrm{SC} \\
(\mathrm{mS} / \mathrm{cm})\end{array}$ & $\begin{array}{l}\text { TDS } \\
(\mathrm{mg} / \mathrm{L})\end{array}$ & $\begin{array}{l}\mathrm{DO} \\
(\mathrm{mg} / \mathrm{L})\end{array}$ & $\mathrm{pH}$ & Eh & $\begin{array}{l}\text { Alkalinity } \\
\left(\mathrm{mg} / \mathrm{L} \text { as } \mathrm{CaCO}_{3}\right)\end{array}$ & $\begin{array}{l}\text { Total gas } \\
\text { pressure } \\
\text { (mBar) }\end{array}$ \\
\hline \multicolumn{12}{|c|}{ MRVA aquifer } \\
\hline Chicot 1 & 27 & Backswamp & $07 / 08 / 13$ & 19.85 & 3.24 & ND & 13.43 & 6.5 & 98.8 & 416 & 799 \\
\hline Chicot 2 & $<30$ & Point bar & $07 / 09 / 13$ & 19.99 & 2.56 & 1,664 & 1.35 & 6.64 & 109.6 & 406 & 803 \\
\hline Chicot 3 & $<30$ & Point bar & $07 / 09 / 13$ & 19.7 & 4.79 & 3,116 & 0.2 & 6.46 & 104.2 & 410 & 814 \\
\hline Desha 1 & 27 & Backswamp & $07 / 10 / 13$ & 18.38 & 0.47 & 308 & 0.15 & 6.39 & 63 & 230 & 788 \\
\hline Desha 2 & 30 & Backswamp & $07 / 10 / 13$ & 19.54 & 2.05 & 1,333 & 0.68 & 6.16 & 129.2 & 348 & 808 \\
\hline Desha 3 & 30 & Point bar & $07 / 11 / 13$ & 18.99 & 1.11 & 725 & 0.33 & 6.31 & 95.8 & 358 & 810 \\
\hline \multicolumn{12}{|c|}{ Middle Claiborne aquifer } \\
\hline Sparta 1 & 160 & NA & $07 / 10 / 13$ & 24.27 & 0.32 & 210 & 0.2 & 8.57 & 53.9 & 162.4 & 806 \\
\hline Sparta 2 & 190 & NA & $07 / 11 / 13$ & 22.16 & 0.36 & 237 & 0.2 & 8.45 & 9.2 & 166.2 & 786 \\
\hline \multicolumn{12}{|c|}{ Lower Claiborne aquifer } \\
\hline Artesian & $\sim 220$ & NA & $07 / 09 / 13$ & 36.38 & 4.28 & 2,781 & 0.05 & 7.99 & 47.5 & 1,012 & 800 \\
\hline
\end{tabular}

bgs below ground surface; $C$ Celsius; $S C$ specific conductance; $T D S$ total dissolved solids; $\mathrm{mS} / \mathrm{cm}$ milliSiemens per centimeter; $D O$ dissolved oxygen; ORP oxidation reduction potential; $m V$ milliVolt; $m g / L$ milligrams per liter; $m B a r$ millibars of mercury; $N A$ not applicable; $N D$ not determined

Noble gas samples were collected using tubing with flow control to minimize air bubbles and retained in copper tubes sealed with compression clamps.

\section{Laboratory procedures}

Major anion (bromide, chloride, fluoride, nitrate, nitrite, phosphate, and sulfate) and cation (calcium, magnesium, potassium, and sodium) analyses were performed on all groundwater samples at the University of Memphis using a Dionex 2000i ion chromatography unit and Varian FS220 atomic adsorption spectrometer, respectively. The accuracy of bromide, chloride, fluoride, and sulfate is within $6 \%$ of the mean. The precision of bromide, chloride, and sulfate is also within $6 \%$ of the mean. The reproducibility of magnesium, potassium, and sodium is within $3 \%$ of the mean. Duplicate sample analyses are within $10 \%$ for most major solutes, except bromide, nitrate and phosphate, which all had concentrations close to their respective method detection limits in the duplicate sample. All but one sample have an ionic charge balance error less than $10 \%$ and most analyses are within $5 \%$. Trace metals for all samples were analyzed by the University of Mississippi using inductively coupled plasma mass spectrometry. Duplicates for most trace elemental analyses are within $10 \%$, except ${ }^{27} \mathrm{Al}$ and ${ }^{66} \mathrm{Zn}$, which are within 31 and $13 \%$, respectively.

Stable isotopes of carbon, hydrogen, and oxygen were analyzed at the University of Arkansas Stable Isotope Lab. Stable hydrogen and oxygen isotope compositions were measured through a High Temperature Conversion Element Analyzer (TCEA) with an experimental error of less than $0.5 \%$ for $\delta^{18} \mathrm{O}$ and $\delta^{2} \mathrm{H}$. Stable carbon isotope concentrations were determined through an elemental analyzer (EA) with an experimental error of less than $0.1 \%$ for $\delta^{13} \mathrm{C}$. Dissolved inorganic carbon (DIC) and dissolved organic carbon (DOC) concentrations were also measured at the University of Arkansas Stable Isotope Lab. Analyses of duplicate samples are within $7 \%$ for DIC and 3\% for DOC.

Five copper tube and ${ }^{3} \mathrm{H}$ bottle samples were submitted to the University of Utah Dissolved and Noble Gas Lab for analysis. Noble gas concentrations were measured by quadrupole mass spectrometry and isotopes of helium on a MAP 215-50 mass spectrometer at the University of Utah Dissolved Gas Lab to a precision of approximately $\pm 0.5 \%$. Tritium concentrations were determined through the helium in-growth method (Clarke et al. 1976) at the University of Utah lab with a practical detection limit of 0.05 TU (Solomon and Cook 2000). Four ${ }^{14} \mathrm{C}$ samples were analyzed by the National Ocean Sciences Accelerator Mass Spectrometry (NOSAMS) facility in Woods Hole, Massachusetts. The carbon from the groundwater sample was sputtered with heated cesium and the ions produced were extracted and separated by mass. Stable carbon isotope ions were measured in Faraday cups, and the radioactive ${ }^{14} \mathrm{C}$ ions were counted using gas ionization (NOSAMS 2015). The ratios between stable and radioactive carbon are used to correct for nonatmospheric sources of carbon and determine a radiocarbon age (NOSAMS 2015).

Helium-3 dissolved in groundwater arises from four sources: atmospheric equilibration, ${ }^{3} \mathrm{H}$ decay, shallow subsurface nuclear reactions, and the mantle (Solomon and Cook 2000). The noble gas composition was used to determine the recharge temperature by the closed-equilibrium excess air (EA) model developed by Aeschbach-Hertig et al. (2000). Shallow subsurface nuclear reactions generate ${ }^{3} \mathrm{He}$ from 
fission of ${ }^{6} \mathrm{Li}$ produced during $\mathrm{U}$ - and Th-series decay. The resulting ${ }^{3} \mathrm{He} /{ }^{4} \mathrm{He}$ ratio from such reactions is approximately $1 \times 10^{-8}$, which is two orders of magnitude less than that of the atmosphere $\left(1.36 \times 10^{-6}\right.$ at $\left.10^{\circ} \mathrm{C}\right)$. Relatively large amounts of ${ }^{4} \mathrm{He}$ from shallow subsurface reactions must be present for this to be an important factor. Nonetheless, ${ }^{3} \mathrm{He}$ from shallow subsurface reactions are accounted for using ${ }^{3} \mathrm{He} /{ }^{4} \mathrm{He}$ ratio of terrigenic (crustal-produced) helium and using neon to correct for atmospheric ${ }^{4} \mathrm{He}$ contributions. Mantle helium has a ${ }^{3} \mathrm{He} /{ }^{4} \mathrm{He}$ ratio approximately ten times greater than that of atmospheric helium; thus, small contributions of mantle helium may be difficult to detect.

The ${ }^{3} \mathrm{H} /{ }^{3} \mathrm{He}$ age of a groundwater sample is defined by Eq. (1):

$t=\lambda^{-1} \times \ln \left({ }^{3} \mathrm{He}_{\mathrm{t}} /{ }^{3} \mathrm{H}+1\right)$

where $\lambda$ is the tritium decay constant, ${ }^{3} \mathrm{He}_{\mathrm{t}}$ is tritiogenic ${ }^{3} \mathrm{He}$, and $t$ is the age in years of the modern ( $<50$ years old) component of the water. Tritiogenic helium is calculated using the EA model to correct for the excess atmospheric gas entrained during percolation of water through the vadose zone (Solomon and Cook 2000). Considering that all possible measures were taken to minimize error and gas loss, it is reasonable to assume, based on past sampling experience and replicate analyses, that the sum of the errors is less than $10 \%$ of the age determination.

\section{Results}

\section{Well sampling rationale}

Factor analysis of 165 chemical analyses revealed two chemically distinct groups of groundwater in the MRVA aquifer (Fig. 3). Eigenvector 1 accounts for $91 \%$ of the variance in groundwater chemistry between all samples and assigned negative loading to calcium, chloride, magnesium, sodium, and sulfate. Eigenvector 2 accounts for $4 \%$ of the variance of groundwater chemistry and has positive loading on chloride and negative loading on calcium and sulfate. Three other eigenvectors accounted for the remaining $5 \%$ of variance in the factor analysis. The "Fresh" group of groundwater samples is highly clustered (Fig. 3a), reflecting water of similar composition that are largely unaffected by saline water sources. The "saline" group of groundwater samples is distributed, reflecting different degrees of salinity. The compositional characteristics of MRVA aquifer wells sampled in this study relative to the USGS database illustrate fresh to saline compositional characteristics (Fig. 3b).

Similar to the MRVA aquifer, two chemically distinct groups of groundwater are observed in the Middle Claiborne aquifer through factor analysis of 55 USGS groundwater samples (Fig. 4). Eigenvector 1 accounts for $84 \%$ of the variance in groundwater chemistry and has negative loading on chloride and sodium. Eigenvector 2 accounts for $9 \%$ of variance in groundwater chemistry and has positive loading on calcium and chloride and negative loading on sodium. Three other eigenvector chemical groups accounted for the remaining $7 \%$ of the variance in the factor analysis. Again, "fresh" and "saline" compositional groups are identified in the Middle Claiborne aquifer, similar to the MRVA aquifer (Fig. 4). The Middle Claiborne aquifer wells sampled in this study relative to the USGS data illustrate fresh compositional characteristics (Fig. 4).

\section{Field measurements}

Field measurements collected during groundwater sampling are presented in Table 1. Water temperature, $\mathrm{pH}, \mathrm{DO}$, and ORP vary by aquifer. Water temperatures from the MRVA aquifer range from 19.0 to $20.0{ }^{\circ} \mathrm{C}$. The Middle Claiborne aquifer water temperatures averaged $23.3{ }^{\circ} \mathrm{C}$, whereas that of the Lower Claiborne well water was $36.4{ }^{\circ} \mathrm{C}$. The $\mathrm{pH}$ values from the Middle and Lower Claiborne wells are slightly basic, whereas groundwater samples from the MRVA aquifer are slightly acidic. Based on DO and ORP values, groundwater from the MRVA aquifer is more oxidized compared to groundwater from the Middle and Lower Claiborne aquifers. The Chicot $1 \mathrm{DO}$ value is anomalously high due to equipment malfunction.

Specific Conductance values from MRVA aquifer groundwater vary by well (Table 1). Sample Chicot 3 recorded the highest $\mathrm{SC}$ value, but other MRVA aquifer wells sampled in Chicot County produced relatively high $\mathrm{SC}$ values also. The SC of sample Desha 2 is similar to the Chicot County MRVA aquifer samples, but samples Desha 1 and Desha 3 have relatively low SC values, with Desha 1 being characteristic of the fresh water group (Fig. 4b). The two Middle Claiborne aquifer groundwater samples showed relatively low SC values and nearly identical values for other field values. The Lower Claiborne aquifer water sample had a similar SC value to Chicot 3.

\section{Major and minor solutes}

Major and minor element concentrations are reported in Table 2. The major solute composition of the samples collected in this study is shown on a Piper diagram (Fig. 5). Chemical data from streams in the study area, including the Arkansas River, Bayou Bartholomew, and Mississippi River, are also plotted for comparison (USGS NWIS 2014). The Piper diagram illustrates that the lower SC samples (Desha 1, Desha 3, Sparta 1, and Sparta 2) are bicarbonate-carbonate type waters, whereas the higher SC samples (Chicot 1, Chicot 2, Chicot 3, Desha 2, and Artesian) are mixed anion to chloride type 
Fig. 3 a Plot of principal eigenvectors showing distinct chemical groups of groundwater from the MRVA aquifer of SE AR. b Plot of the principal eigenvectors for chemistry of wells screened in the MRVA aquifer sampled in this study relative to the compositional range of USGS data
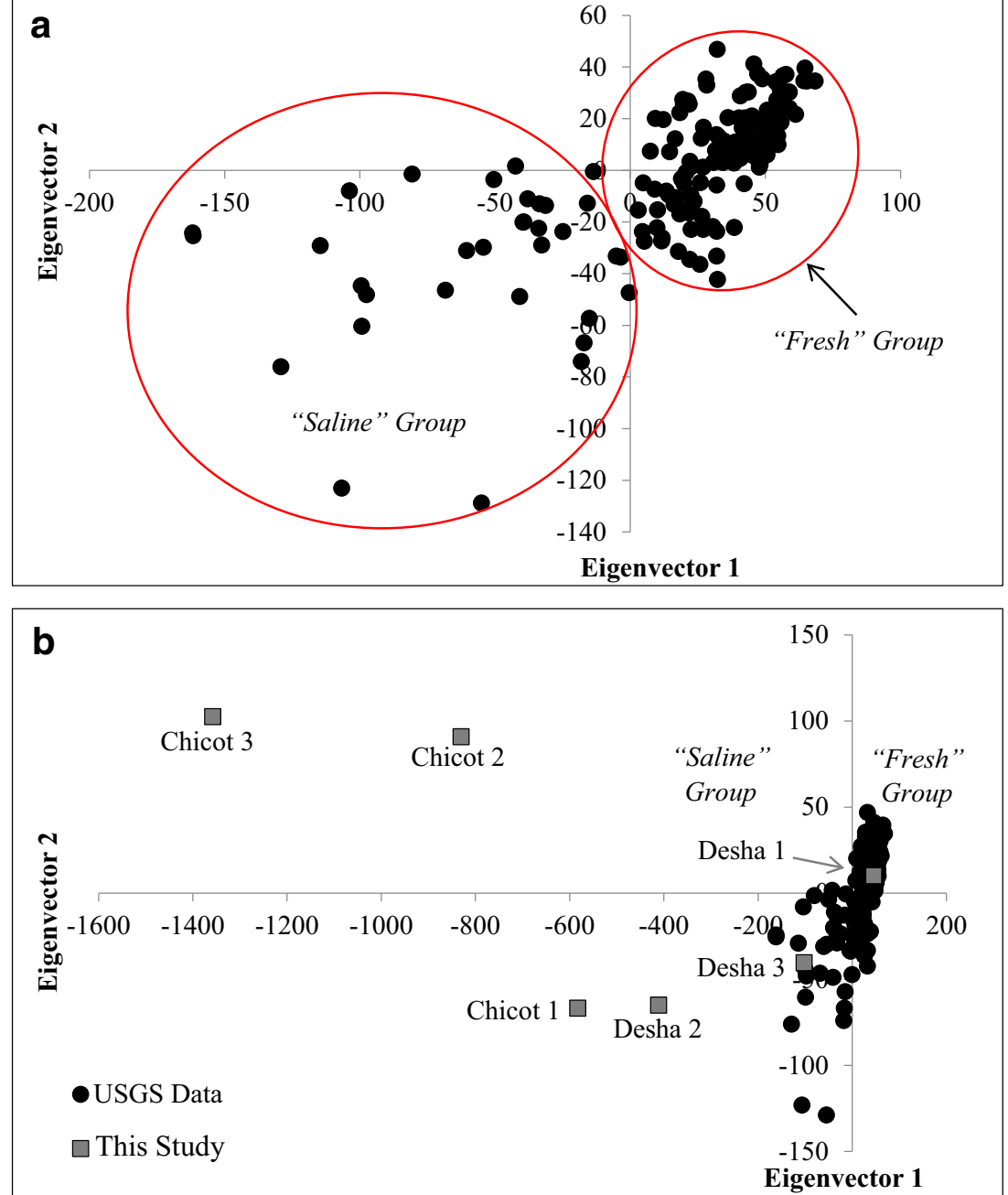

waters. MRVA aquifer groundwater samples display mixed proportions of calcium, magnesium, potassium, and sodium. The water samples from the Middle and Lower Claiborne aquifers are dominated by sodium and classified as sodium type waters.

Fig. 4 Plot of the principal eigenvectors for wells screened in the Middle Claiborne aquifer showing distinct chemical groups of groundwater. The wells sampled in this study plot in the "fresh" group relative to the compositional range of USGS data
Molar concentrations of sodium and chloride in groundwater samples collected during this study are plotted with data from the Sparta, Lower Claiborne, and Wilcox aquifers in the northern ME (Haile 2011), Wilcox aquifers in the southern ME (McIntosh et al. 2010), Smackover Formation in southern

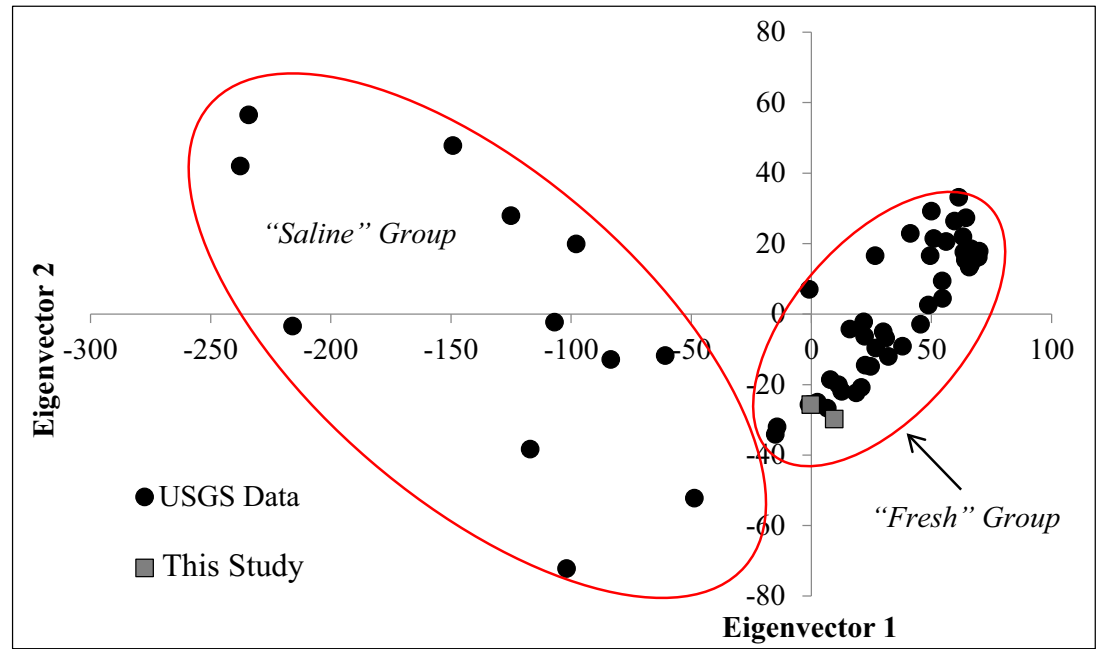




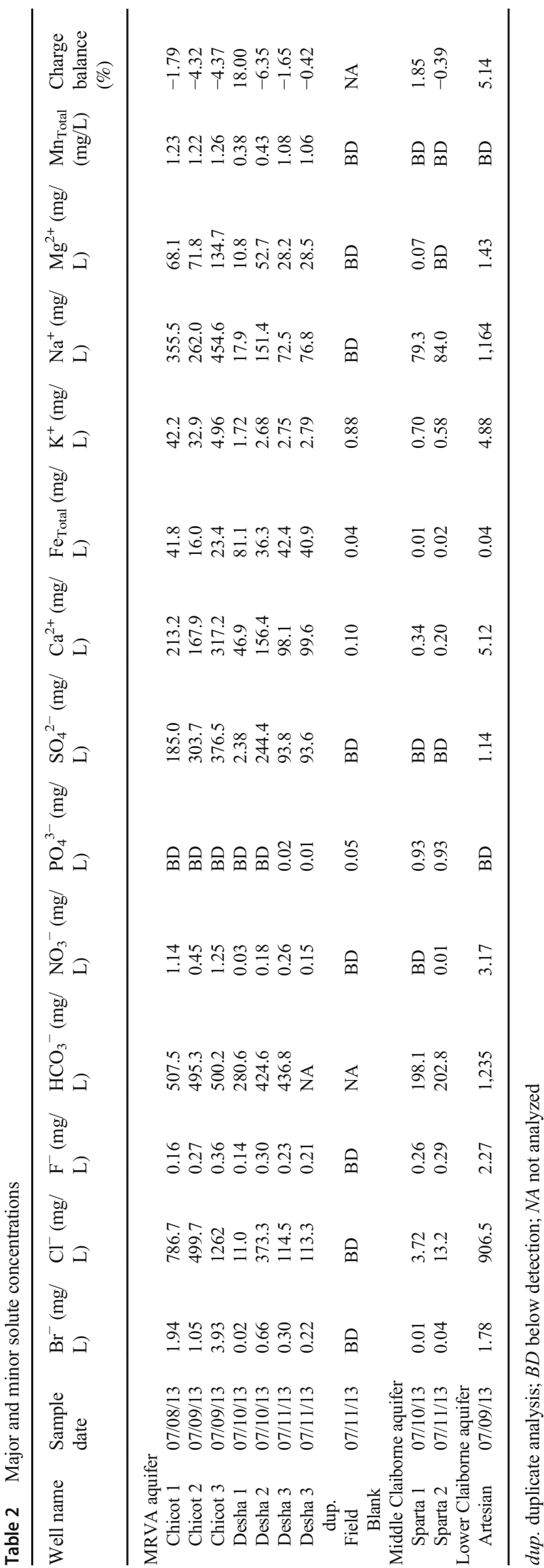

Arkansas (Carpenter and Trout 1978), and time-averaged data from the Arkansas River, Bayou Bartholomew, and Mississippi River (USGS NWIS 2014) (Fig. 6). The low SC MRVA aquifer water sample (Desha 1) has sodium and chloride contents similar to those of the rivers in the study area, unlike the higher SC samples (Desha 2, Chicot 1, Chicot 2, and Chicot 3). Desha 3 lies on the halite dissolution line but roughly along a mixing line between the rivers in the study area and the higher SC MRVA samples. However, the higher SC MRVA aquifer water samples follow a mixing relationship with water samples from the Smackover Formation.

Mixing relationships between MRVA aquifer and Smackover Formation waters are evident for molar chloride and bromide (Fig. 7) as well as most metals and bromide (Fig. 8) (Paul 2015). The higher SC water samples from the MRVA aquifer are enriched in bromide relative to chloride along a linear trend with the Smackover Formation that has a lower slope than that of seawater evaporation. The trend line between MRVA aquifer and Smackover Formation waters for calcium and bromide shows a deviation toward lower calcium with higher bromide in the MRVA water samples, suggesting either calcite precipitation or mixing with Lower Wilcox Formation water.

\section{Trace element data}

Trace element data for the groundwater samples are presented in Table 3. Trace element concentrations vary by aquifer with the MRVA aquifer water samples enriched in barium, strontium, and zinc relative to the Middle and Lower Claiborne aquifer samples. The Lower Claiborne aquifer sample is enriched in lithium compared to MRVA and Sparta aquifer samples. Lithium and strontium show crude linear correlations with bromide (Paul 2015).

\section{Stable and radiocarbon isotopes}

Stable isotope, radiocarbon and associated data are tabulated in Table 4. Stable hydrogen and oxygen isotope values along with other relevant data are plotted to evaluate relationships to meteoric water and evaporative evolution (Fig. 9). The groundwater samples from this study plot to the right of the Global Meteoric Water Line (GMWL) and Arkansas MWL, suggesting influence by evaporative evolution, water-rock, mixing, or a combination of these processes. The MRVA aquifer water samples from SE AR also exhibit a linear trend with a shallower slope $(\mathrm{m}$ 4.4) than those of the Global and Arkansas MWLs, consistent with evaporative fractionation. However, stable hydrogen and oxygen data from other wells screened in the MRVA aquifer in the southern ME (USGS NWIS 2020) do not show evidence of extensive evaporation, do not overlap with the data in this project, and overall exhibit a steeper slope $(\mathrm{m} \sim 5.2)$. Moreover, the trend of the MRVA 
Fig. 5 Piper diagram showing composition of groundwater samples collected in this study and streams in the study area, including the Arkansas River, Bayou Bartholomew, and Mississippi River (from Paul 2015). Stream data from USGS (USGS NWIS 2014)

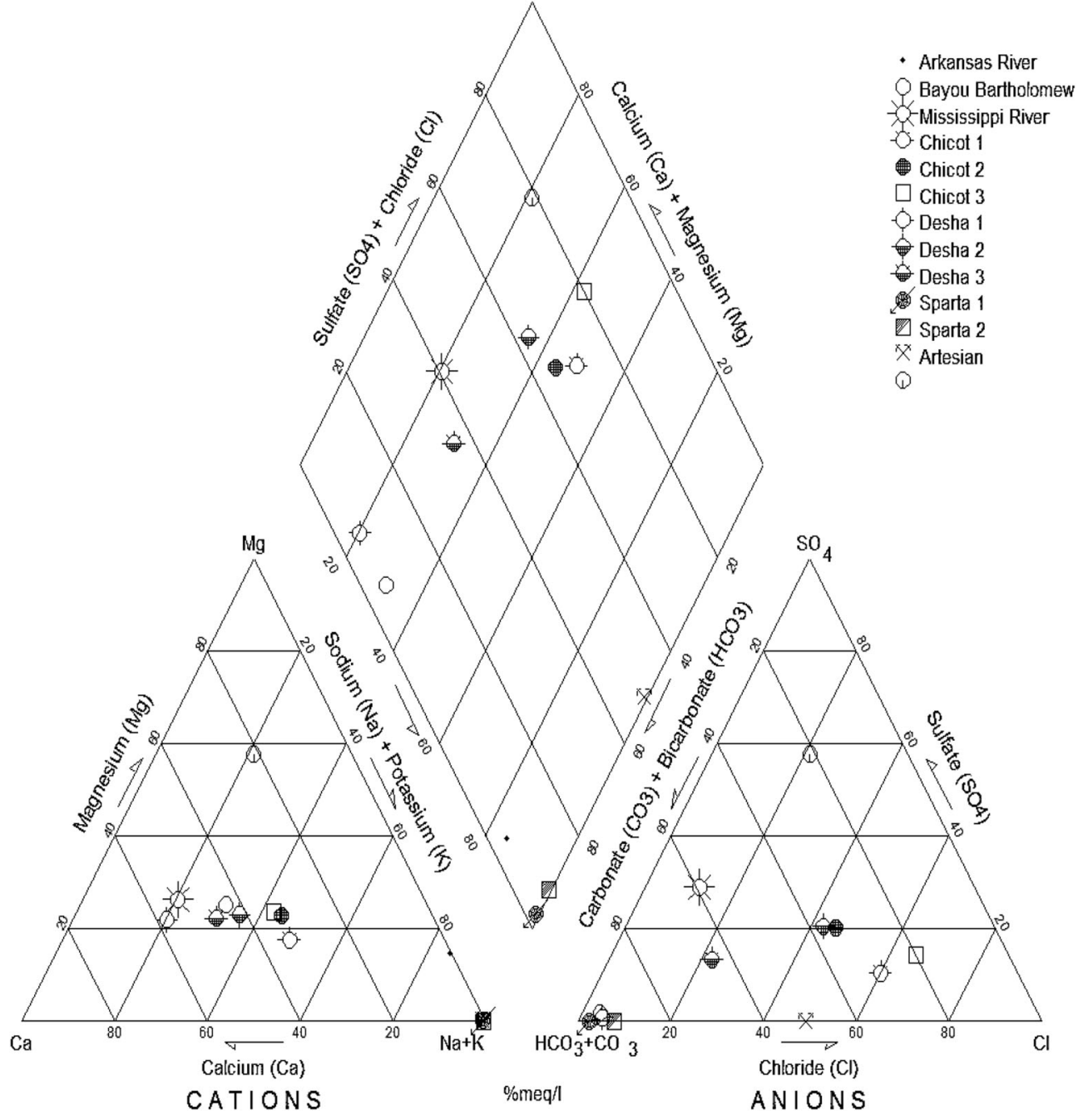

aquifer water samples fits mixing with water from the Lower Wilcox aquifer in the southern ME (McIntosh et al. 2010), with sample Chicot 2 plotting within the Lower Wilcox field.

Stable carbon $\left(\delta^{13} \mathrm{C}\right)$ isotope values from DIC of groundwater samples collected in this study range between -9.41 and $-18.1 \%$ and vary by aquifer (Table 4 ). Typical stable carbon isotope values from the atmosphere are -7 to $-8 \%$ o (Deines 1980), whereas typical stable carbon isotope values from plant material range between -12 and $-25 \%$ (Kendall and Doctor 2005). Thus, samples from the MRVA and Middle Claiborne aquifers indicate substantial oxidation of organic carbon, whereas that for the Lower Claiborne aquifer is closer to atmospheric fractionation.

Radiocarbon ages of the MRVA aquifer water samples ranged from 280 radiocarbon years before present (C-14 ybp) in sample Desha 1, the most dilute of the MRVA samples, to 1,530 C-14 ybp in sample Chicot 3, the most concentrated of the MRVA samples. The radiocarbon age of the Middle Claiborne aquifer water sample analyzed is considerably older at 47,200 C$14 \mathrm{ybp}$. The radiocarbon age of the MRVA aquifer samples increases with chloride content (Fig. 10), independently supporting mixing between young, fresh and old, saline sources of groundwater as discussed in the preceding sections.

\section{Noble gases and tritium}

Noble gas and tritium data are presented in Table 5. The recharge temperatures of the MRVA aquifer water samples range from $11.58{ }^{\circ} \mathrm{C}$ to $16.40{ }^{\circ} \mathrm{C}$, whereas the recharge temperature from the Middle Claiborne aquifer water sample is $10.85^{\circ} \mathrm{C}$.

Helium isotopes are useful for determining reservoirs in the Earth from which helium in groundwater is derived. $R / R_{\mathrm{a}}$ ratios, which measure the ${ }^{3} \mathrm{He}$ to ${ }^{4} \mathrm{He}$ ratio in a sample relative to an atmospheric standard, indicate the helium content in samples Desha 1, Desha 2, and Desha 3 is consistent with an atmospheric source (i.e. precipitation), whereas the low $(<1)$ $R / R_{\mathrm{a}}$ value for Chicot 2 indicates that part of the helium content in the sample is derived from crustal sources (Kulongoski and Hilton 2011). The helium content in the Middle Claiborne 


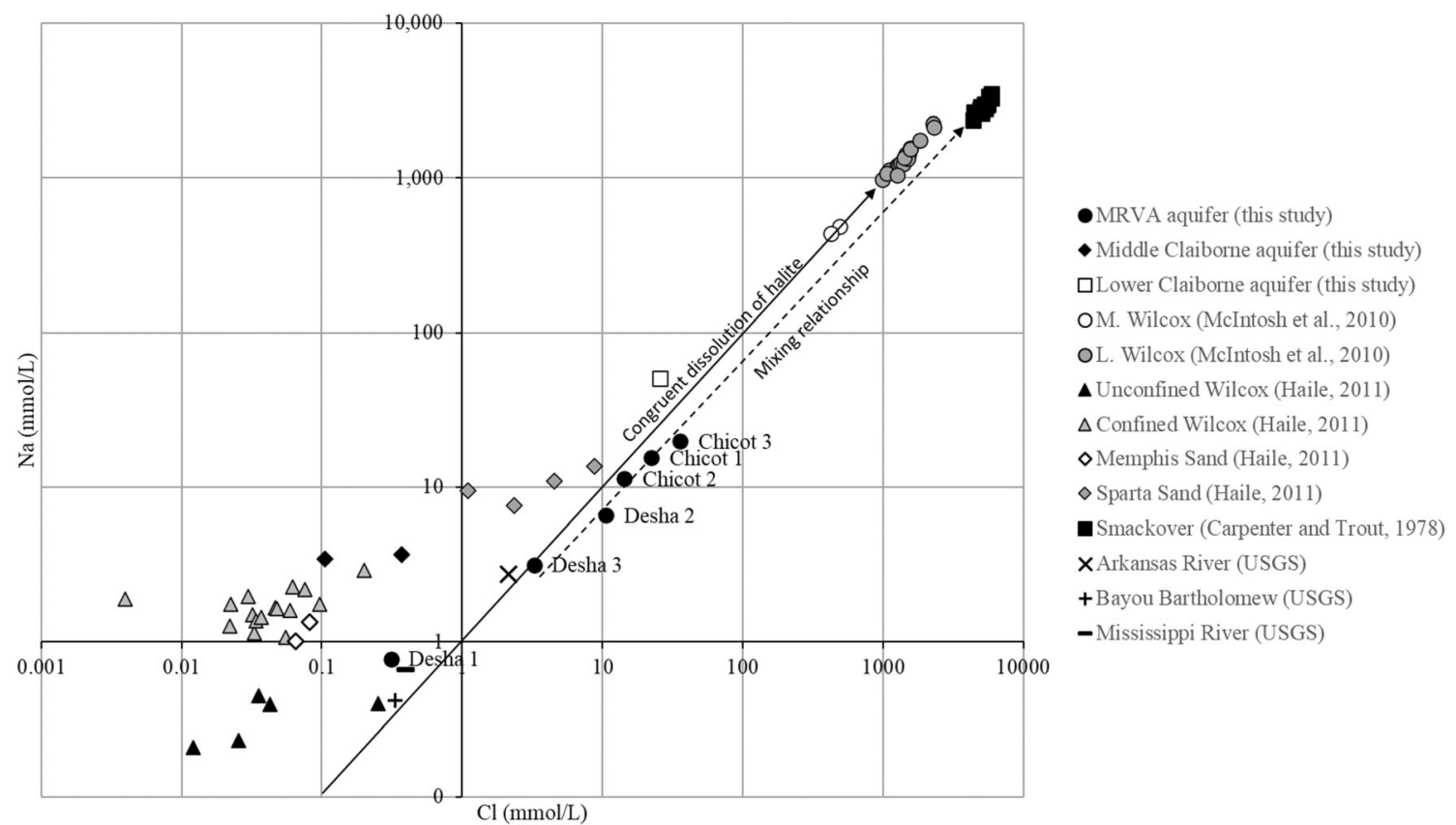

Fig. 6 Molar concentrations of sodium and chloride from samples in this study and data from the Middle Claiborne, Lower Claiborne, and Wilcox aquifers in the northern ME (Haile 2011), Wilcox aquifers in the southern ME (McIntosh et al. 2010), Smackover Formation in southern Arkansas

aquifer water sample is much greater than atmospheric helium contents and is dominated by crustal ${ }^{4} \mathrm{He}$.

Helium- 4 concentrations are plotted against $R / R_{\mathrm{a}}$ values to further assess sources of helium in groundwater samples (Fig. 11). Equations (2) and (3) were used to model the theoretical ${ }^{4} \mathrm{He}$ production curve. Equation (2) was used to
(Carpenter and Trout 1978), and time-averaged data from the Arkansas River, Bayou Bartholomew, and Mississippi River (USGS NWIS 2014). Site symbols correspond with those in Fig. 1

calculate theoretical ${ }^{4} \mathrm{He}$ production $\left(C_{w}\right)$ in $\mu \mathrm{cm}^{3} \mathrm{STP} \mathrm{kg}^{-1}$ through time $(\tau)$ (Solomon 2000)

$\tau=C_{w} / G C_{1}[(1 / n)-1]$

where $G$ is the ${ }^{4} \mathrm{He}$ release rate per unit volume of solids per unit of time in atoms $\mathrm{m}^{-3} \mathrm{~s}^{-1}, C_{1}$ is a conversion factor of

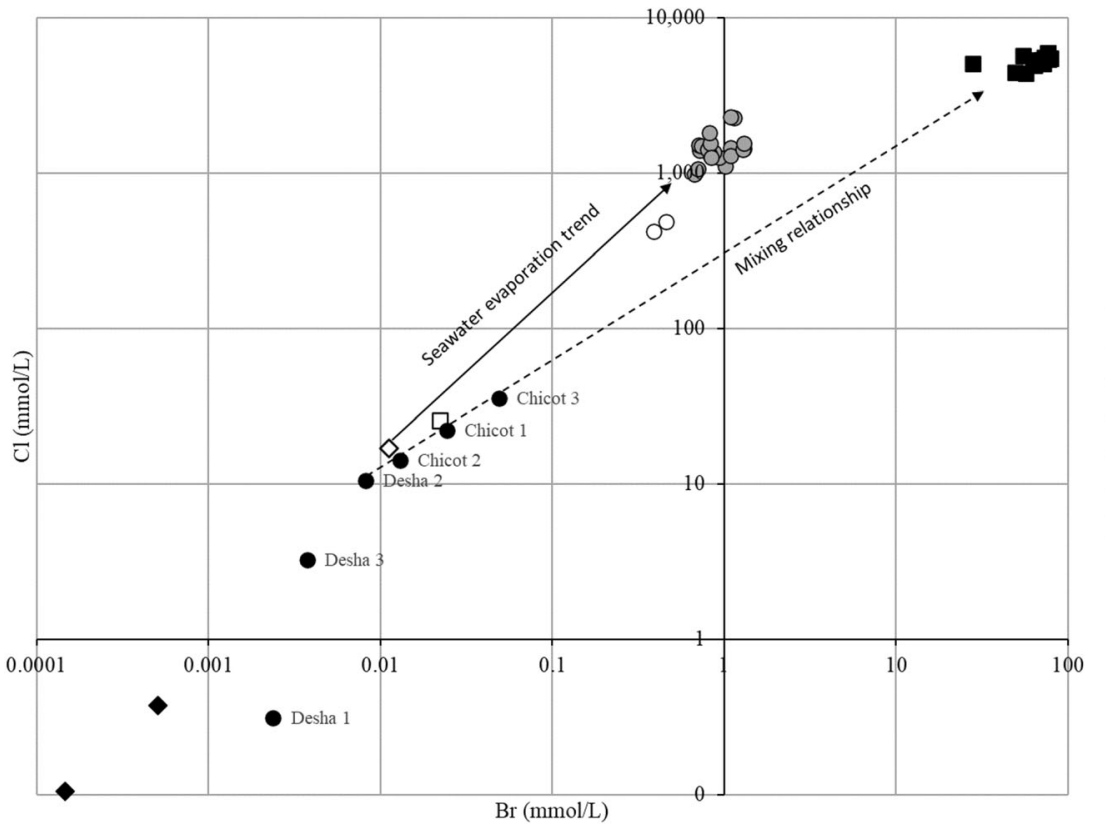

- MRVA aquifer (this study)

- Middle Claiborne aquifer (this study) 口Lower Claiborne aquifer (this study) OM. Wilcox (McIntosh et al., 2010) OL. Wilcox (McIntosh et al., 2010) $\diamond$ Seawater (McCaffrey et al., 1987)

- Smackover (Carpenter and Trout, 1978)
Fig. 7 Molar concentrations of chloride and bromide in samples from this study as well data from the Wilcox aquifers in the southern ME (McIntosh et al. 2010), Smackover Formation in southern Arkansas
(Carpenter and Trout 1978), and average seawater (McCaffrey et al. 1987). Site symbols correspond with those in Fig. 1 


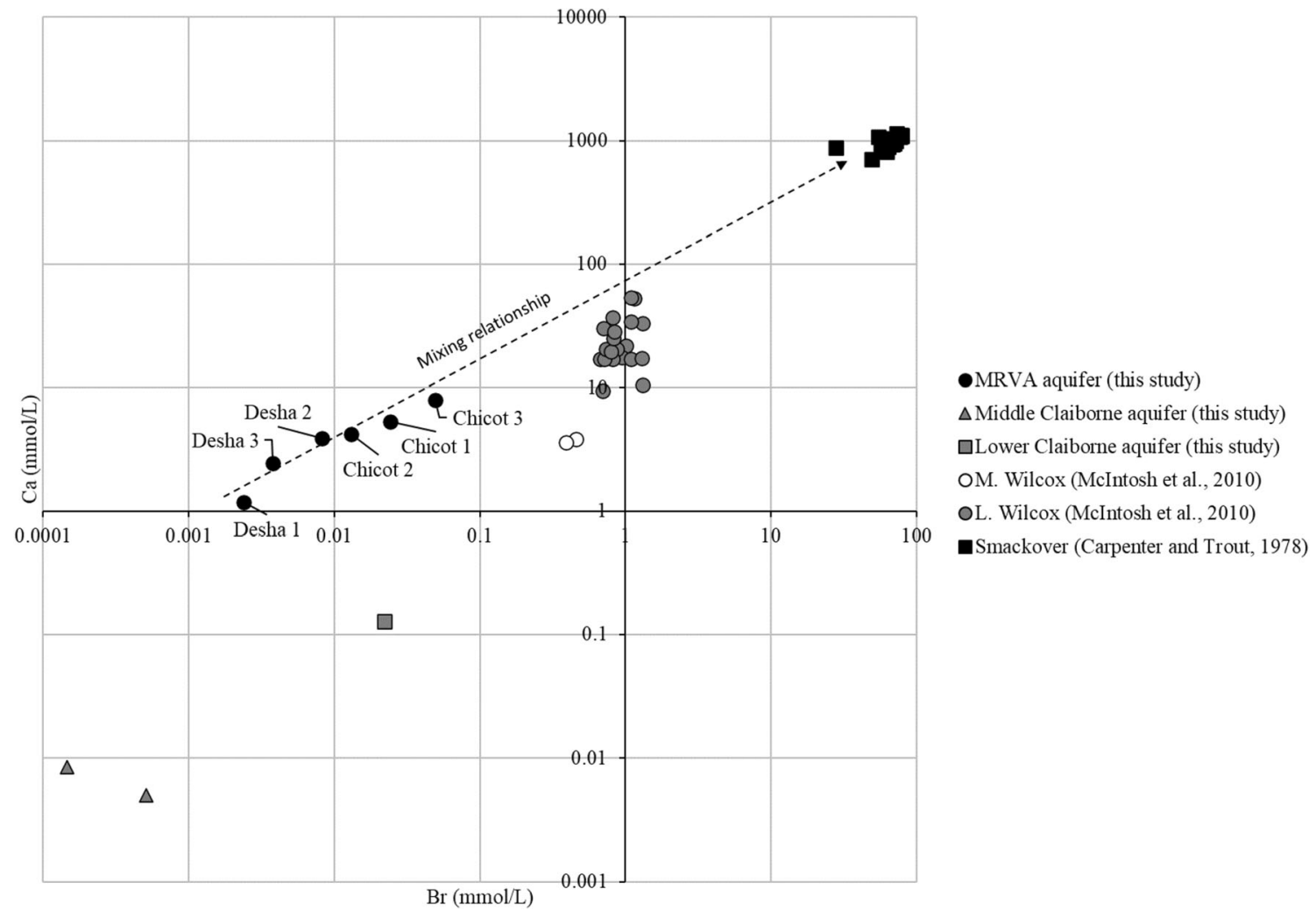

Fig. 8 Molar concentrations of calcium and bromide in samples from this study and data from the Wilcox aquifers in the southern ME (McIntosh et al. 2010) and Smackover Formation in southern Arkansas (Carpenter and Trout 1978). Site symbols correspond with those in Fig. 1

$3.7197 \times 10^{-14}$ in $\mu \mathrm{cm}^{3} \mathrm{STP}$ atom ${ }^{-1}$, and $n$ is the fractional porosity of the aquifer, which is dimensionless. $G$ is assumed to be 2 , which is an intermediate ${ }^{4} \mathrm{He}$ production rate in sedimentary rocks (Solomon 2000). The fractional porosity is assumed to be $20 \%$ for mixed sand, silt, and clay units (Fetter 2001). Equation (3) was used to calculate resultant $R / R_{\mathrm{a}}$ values based on $C_{w}$ (Solomon 2000)

$R / R_{\mathrm{a}}={ }^{3} \mathrm{He}_{\mathrm{atm}} /\left[C_{w}+\left({ }^{4} \mathrm{He}_{\text {Desha } 1}\right) / R_{\mathrm{a}}\right]$

Table 3 Trace element data

\begin{tabular}{|c|c|c|c|c|c|c|c|c|c|}
\hline Well name & Sample date & ${ }^{27} \mathrm{Al}(\mu \mathrm{g} / \mathrm{L})$ & ${ }^{137} \mathrm{Ba}(\mu \mathrm{g} / \mathrm{L})$ & ${ }^{59} \mathrm{Co}(\mu \mathrm{g} / \mathrm{L})$ & ${ }^{52} \mathrm{Cr}(\mu \mathrm{g} / \mathrm{L})$ & ${ }^{7} \mathrm{Li}(\mu \mathrm{g} / \mathrm{L})$ & ${ }^{85} \mathrm{Rb}(\mu \mathrm{g} / \mathrm{L})$ & ${ }^{88} \mathrm{Sr}(\mu \mathrm{g} / \mathrm{L})$ & ${ }^{66} \mathrm{Zn}(\mu \mathrm{g} / \mathrm{L})$ \\
\hline \multicolumn{10}{|l|}{ MRVA aquifer } \\
\hline Chicot 1 & $07 / 08 / 13$ & $\mathrm{BD}$ & 38 & 0.17 & $\mathrm{BD}$ & 19 & 4.0 & 3,200 & 29 \\
\hline Chicot 2 & $07 / 09 / 13$ & $\mathrm{BD}$ & 94 & 0.30 & $\mathrm{BD}$ & 16 & 4.1 & 2,900 & $\mathrm{BD}$ \\
\hline Chicot 3 & $07 / 09 / 13$ & $\mathrm{BD}$ & 210 & 0.11 & 0.45 & 24 & 4.7 & 5,300 & 32 \\
\hline Desha 1 & $07 / 10 / 13$ & $\mathrm{BD}$ & 260 & 0.42 & 0.41 & 5.0 & 1.1 & 570 & $\mathrm{BD}$ \\
\hline Desha 2 & $07 / 10 / 13$ & $\mathrm{BD}$ & 270 & 0.44 & $\mathrm{BD}$ & 8.5 & 2.3 & 2,400 & $\mathrm{BD}$ \\
\hline Desha 3 & $07 / 11 / 13$ & $\mathrm{BD}$ & 740 & 0.13 & $\mathrm{BD}$ & 15 & 3.0 & 1,600 & 41 \\
\hline Desha 3 duplicate & $07 / 11 / 13$ & $\mathrm{BD}$ & 700 & 0.14 & $\mathrm{BD}$ & 15 & 2.8 & 1,500 & 47 \\
\hline Field Blank & $07 / 11 / 13$ & 6.8 & 3.5 & 0.010 & 0.29 & 0.57 & 0.37 & 0.78 & 29 \\
\hline \multicolumn{10}{|c|}{ Middle Claiborne aquifer } \\
\hline Sparta 1 & $07 / 10 / 13$ & 8.6 & 4.6 & 0.11 & $\mathrm{BD}$ & 5.6 & 0.87 & 19 & $\mathrm{BD}$ \\
\hline Sparta 2 & $07 / 11 / 13$ & 6.9 & $\mathrm{BD}$ & 0.16 & 0.47 & 5.9 & 0.85 & 13 & $\mathrm{BD}$ \\
\hline \multicolumn{10}{|c|}{ Lower Claiborne aquifer } \\
\hline Artesian & 07/09/13 & $\mathrm{BD}$ & 81 & 0.10 & $\mathrm{BD}$ & 95 & 5.7 & 1,500 & $\mathrm{BD}$ \\
\hline
\end{tabular}

$B D$ below detection 
Table 4 Stable and radiocarbon isotope data

\begin{tabular}{|c|c|c|c|c|c|c|c|c|c|}
\hline Well name & Sample date & $\delta^{2} \mathrm{H}(\% \circ)$ & $\delta^{18} \mathrm{O}(\% \circ)$ & DIC (ppm) & $\delta^{13} \mathrm{C}(\% \circ)$ & $\begin{array}{l}{ }^{14} \mathrm{C} \text { age } \\
(\mathrm{C}-14 \text { ybp })\end{array}$ & $\begin{array}{l}{ }^{14} \mathrm{C} \text { age } \\
\text { error (years) }\end{array}$ & $\begin{array}{l}\text { Fraction } \\
\text { modern carbon }\end{array}$ & $\begin{array}{l}\text { Fraction modern } \\
\text { carbon error }\end{array}$ \\
\hline \multicolumn{10}{|l|}{ MRVA aquifer } \\
\hline Chicot 1 & $07 / 08 / 13$ & -24.04 & -3.25 & 99.9 & -15.36 & NA & NA & NA & NA \\
\hline Chicot 2 & $07 / 09 / 13$ & -14.81 & -0.77 & 105.6 & -16.09 & NA & NA & NA & NA \\
\hline Chicot 3 & $07 / 09 / 13$ & -22.41 & -2.99 & 120.0 & -15.71 & 1,530 & 20 & 0.8261 & 0.0023 \\
\hline Desha 1 & $07 / 10 / 13$ & -25.88 & -3.35 & 63.4 & -17.14 & 280 & 25 & 0.9659 & 0.0031 \\
\hline Desha 2 & $07 / 10 / 13$ & -23.97 & -2.85 & 100.7 & -15.56 & 500 & 20 & 0.9395 & 0.0025 \\
\hline Desha 3 & $07 / 11 / 13$ & -29.26 & -3.94 & 107.2 & -18.05 & NA & NA & NA & NA \\
\hline Desha 3 duplicate & $07 / 11 / 13$ & NA & NA & 104.6 & NA & NA & NA & NA & NA \\
\hline \multicolumn{10}{|c|}{ Middle Claiborne aquifer } \\
\hline Sparta 1 & $07 / 10 / 13$ & -33.80 & -5.01 & 41.0 & -13.60 & 47,200 & 690 & 0.0028 & 0.0002 \\
\hline Sparta 2 & $07 / 11 / 13$ & -33.40 & -5.11 & 38.6 & -13.58 & NA & NA & NA & NA \\
\hline \multicolumn{10}{|c|}{ Lower Claiborne aquifer } \\
\hline Artesian & $07 / 09 / 13$ & -29.62 & -4.48 & 267.9 & -9.41 & NA & NA & NA & NA \\
\hline
\end{tabular}

DIC dissolved inorganic carbon; ppm parts per million; $C$-14 ybp Carbon-14 years before present (1950); NA not analyzed

where ${ }^{3} \mathrm{He}_{\text {atm }}$ is the ${ }^{3} \mathrm{He}$ content of the atmosphere $\left(7.9995 \times 10-14 \mathrm{\mu cm}^{3} \mathrm{STP} \mathrm{kg}^{-1}\right.$ from Solomon 2000) and ${ }^{4} \mathrm{He}_{\text {Deshal }}$ is the ${ }^{4} \mathrm{He}$ content in $\mu \mathrm{cm}^{3}$ STP $\mathrm{kg}^{-1}$ from the "background" MRVA aquifer water sample.

Sample Chicot 2 shows enrichment of ${ }^{4} \mathrm{He}$ relative to Desha 1, Desha 2, and Desha 3. This indicates the ${ }^{4} \mathrm{He}$ content in Chicot 2 has been influenced by mixing with older, deeper groundwater sources with greater ${ }^{4} \mathrm{He}$ contents than "background" MRVA aquifer groundwater. This independently supports the mixing of crustal and atmospheric ${ }^{4} \mathrm{He}$ sources as discussed previously. The lower $R / R_{\mathrm{a}}$ values for Desha 2 and Desha 3 relative to

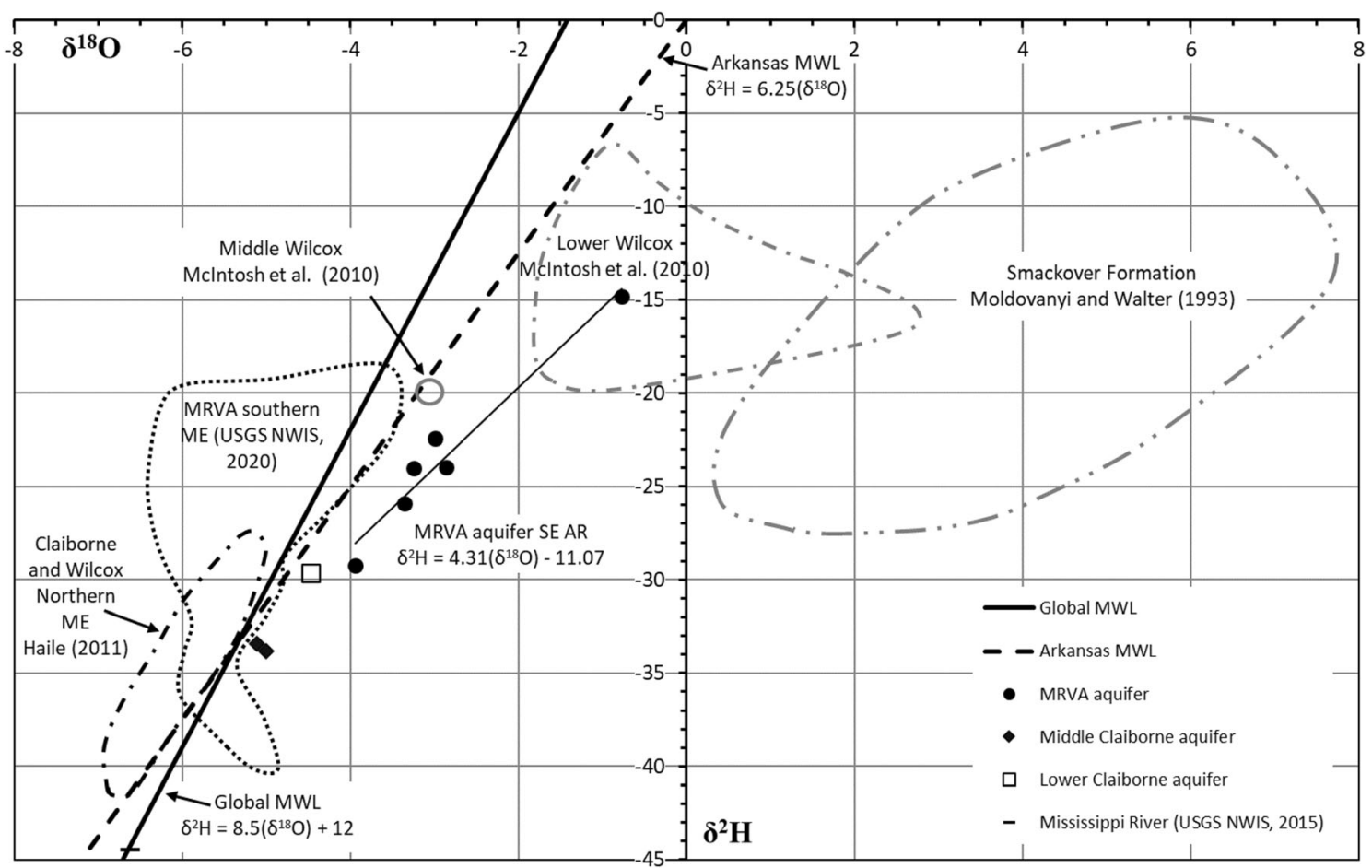

Fig. 9 Stable hydrogen and oxygen isotope values of samples from this study as well as data from the Sparta, Lower Claiborne, and Wilcox aquifers in the northern ME (Haile 2011), Wilcox aquifers in the southern ME (McIntosh et al. 2010), Smackover Formation in Arkansas and Louisiana (Moldovanyi and Walter 1993), MRVA aquifer in southern
ME (USGS NWIS 2020), and Mississippi River (USGS NWIS 2015). The Global Meteoric Water Line (Global MWL; Craig 1961), and Arkansas Meteoric Water Line (Arkansas MWL; Kendall and Coplen 2001) are plotted for reference. Site symbols correspond with those in Fig. 1 


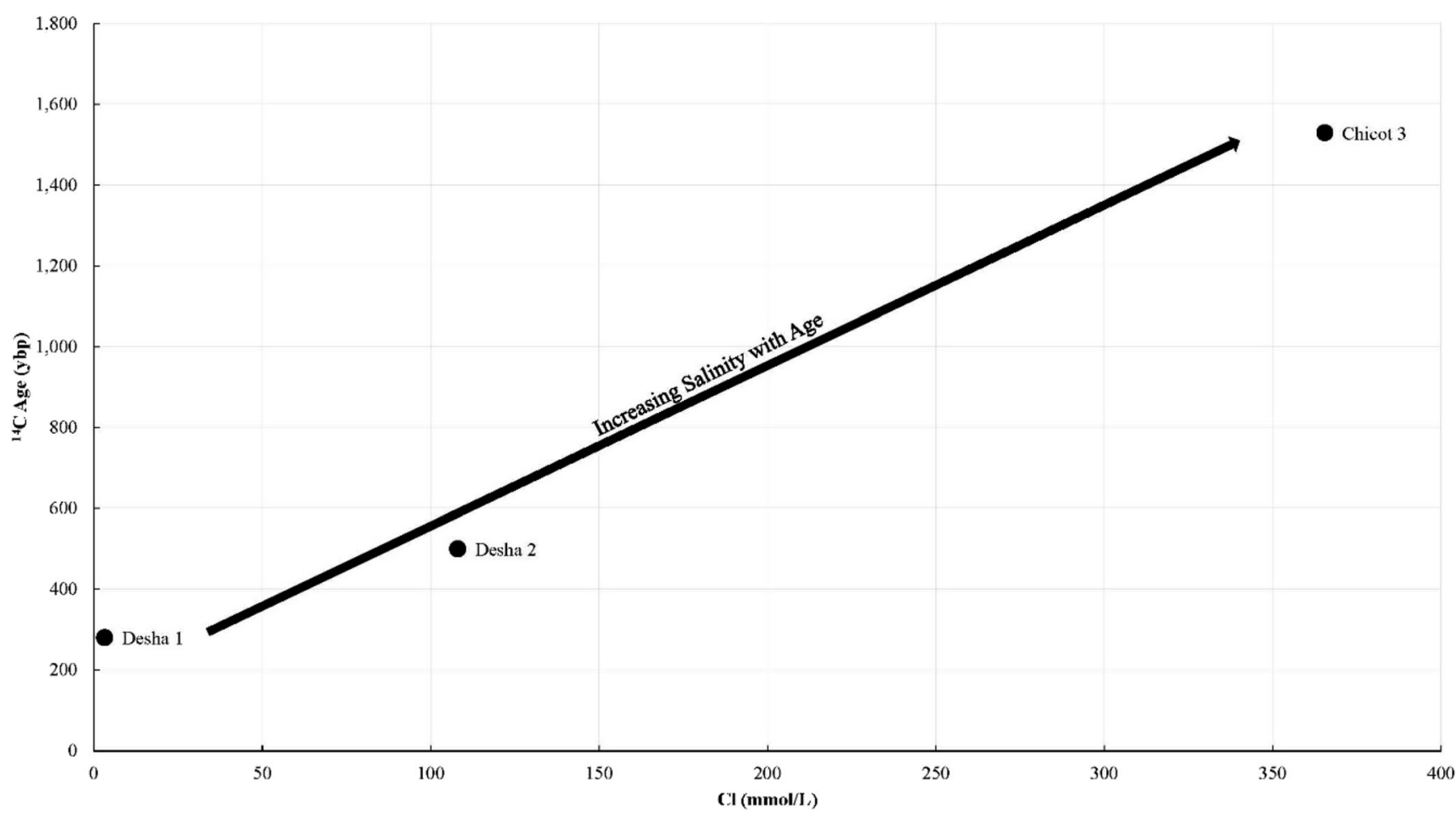

Fig. 10 Radiocarbon age of the MRVA aquifer water samples plotted against the molar concentration of chloride. Site symbols correspond with those in Fig. 1

Desha 1 may also indicate ${ }^{4} \mathrm{He}$ influences from crustal sources.

Tritium is used to detect the presence of modern groundwater (i.e. less than 60 years old). Tritium is detected in all MRVA aquifer water samples indicating each has a component of modern water recharge (Table 5). Sample Chicot 2 is lower in tritium relative to the other samples, whereas sample Desha 1 has higher tritium relative to the other samples. This is consistent with the trend showing sample Desha 1 as having significant modern water (Fig. 11). The lower tritium in sample Chicot 2 is consistent with prominence of pre-modern water in the sample relative to the other samples. This inference is quantified by the ${ }^{3} \mathrm{H} /{ }^{3} \mathrm{He}$ age data (Table 5) showing sample Chicot 2 has an older age relative to the Desha County samples.

\section{Discussion}

\section{Source of salinity the MRVA aquifer in SE AR}

Principal component analysis of existing and new chemistry data from SE AR support the geochemical trends in salinity in groundwater from the MRVA aquifer described by Kresse and Clark (2008) and previous workers. The saline group tends to have high chloride contents that correspond with proportionally lower calcium and sulfate. The saline group from the underlying Middle Claiborne aquifer has high chloride and calcium with proportionally lower sodium. This study did not sample any wells with saline groundwater in the Middle Claiborne aquifer, although the Sparta 1 well is in an area with saline water in the overlying MRVA aquifer (Kresse et al. 2014). The Lower Claiborne aquifer sample is chemically distinct from both the MRVA and Middle Claiborne groundwater, with a Na-Cl$\mathrm{HCO}_{3}$ composition. Neither the Middle Claiborne or Lower Claiborne aquifer samples plot along chemical trend lines with the MRVA aquifer samples, suggesting that they are not significant chemical mixing end-members for the MRVA aquifer water.

Speciation modeling using PHREEQCi (Parkhurst and Appelo 1999) was completed to assess mineral control on the water composition. Modeling of the MRVA aquifer samples indicates that only iron phases (goethite, hematite, magnetite, and siderite) and witherite $\left(\mathrm{BaCO}_{3}\right)$ are consistently oversaturated in the water. Barite and dolomite are oversaturated in the high-chloride waters, and calcium and strontium carbonate phases (aragonite, calcite, and strontianite) are slightly undersaturated. For the Middle Claiborne aquifer samples, only iron phases (goethite, hematite, magnetite, and siderite) and fluorapatite $\left[\mathrm{Ca}_{5}\left(\mathrm{PO}_{4}\right)_{3} \mathrm{~F}\right]$ are consistently oversaturated in the water. For the lower Claiborne sample, carbonate phases (aragonite, calcite, dolomite, strontianite, and witherite) and iron phases (goethite, hematite, and magnetite) are oversaturated. Although the salinity of the Lower Claiborne aquifer sample suggests that it may be a source for MRVA aquifer salinity, the predominance of sodium rather than calcium ions and supersaturation with calcite preclude it as a significant source for the MRVA waters. 


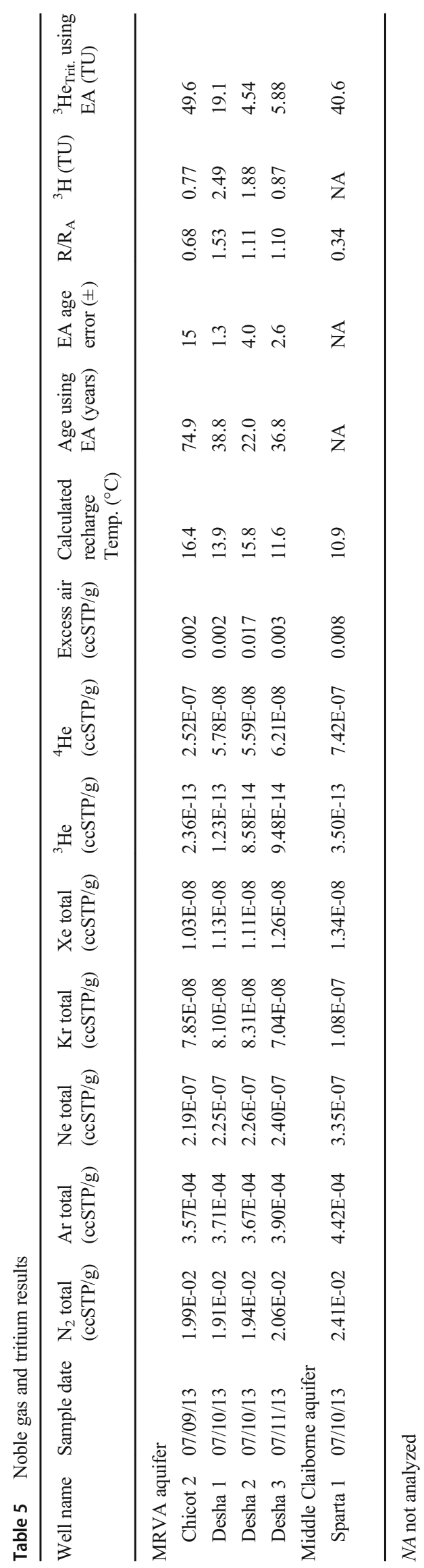

The geochemical and hydrologic tracer results strongly support the principal source of the saline groundwater in the MRVA aquifer being due to the upward migration of premodern water with distinct chemical characteristics from depth in the ME. Mixing of fluids with chemical similarity to the Smackover Formation in southern Arkansas (Carpenter and Trout 1978; Moldovanyi and Walter 1993) and the Lower Wilcox aquifer in Louisiana (McIntosh et al. 2010) with MRVA aquifer water best explain the geochemical trends observed in the chemical data from wells sampled in the study in Chicot and Desha Counties (Figs. 7, 8, and 9). Simple dissolution of $\mathrm{NaCl}$ from salt domes in northern Louisiana will not produce the $\mathrm{Cl}-\mathrm{Br}$ trends observed in the MRVA water (Fig. 7). Fluids from the Smackover Formation and Lower Wilcox aquifer would also have lower ${ }^{14} \mathrm{C}$ activities, greater ${ }^{4} \mathrm{He}$ contents, and lower ${ }^{3} \mathrm{H}$ and $R / R_{\mathrm{a}}$ than modern recharge, consistent with mixing of geological older, crustal water sources (Figs. 10 and 11; Table 5).

Near-surface evaporation of surface or river water cannot solely explain the geochemical and hydrologic tracer results in the chloride-rich MRVA aquifer water samples from this study. The $\mathrm{Na}-\mathrm{Cl}$ trends and $\mathrm{Cl} / \mathrm{Br}$ ratios of the chloride-rich MRVA waters are not consistent with evaporative concentration of local precipitation or river waters (Figs. 6 and 7). Although the stable hydrogen and oxygen trend of the chloride-rich MRVA aquifer waters is consistent with evaporation of regional isotopic values in the MRVA aquifer, the intercept with the Arkansas MWL and Global MWL $\left(\delta^{2} \mathrm{H}=-35 \%\right.$; $\delta^{18} \mathrm{O}=-5.5 \%$; Fig. 9) is not consistent with Mississippi River water and is lower than typical stream discharge in the region (Kendall and Coplen 2001). The slope of the stable hydrogen and oxygen data $(m=4.31)$ from MRVA aquifer water samples in this study is much lower than typical values in the region $(m=5.2-6.25)$ and would be typical of an arid region (Kendall and Coplen 2001). As well, the association of decreasing ${ }^{14} \mathrm{C}$ and increasing ${ }^{4} \mathrm{He}$ with increasing chloride contents is inconsistent with an origin solely of evaporation of surface waters.

The distinct $\mathrm{Cl} / \mathrm{Br}$ ratio of the chloride-rich MRVA aquifer waters is characteristic of pore waters from the Jurassic Smackover Formation and similar hypersaline brines (Hanor 1987). Smackover Formation brines are naturally enriched in bromide as a result of being expelled from evaporite deposits in the middle Jurassic Werner and Louann formations into the upper Jurassic Smackover Formation (Carpenter and Trout 1978; Hanor and McIntosh 2007). Evaporation of sea water to form the Werner and Louann evaporites allowed bromide to become enriched relative to chloride in the formational fluids. Increased calcium with bromide in the MRVA aquifer water samples (Fig. 8) is also consistent with mixing of Smackover Formation fluids because calcium was enriched in the formational fluid due to diagenetic dolomitization (Carpenter and Trout 1978; Hanor and McIntosh 2007), amongst other processes. The proportionally lower calcium contents of the 


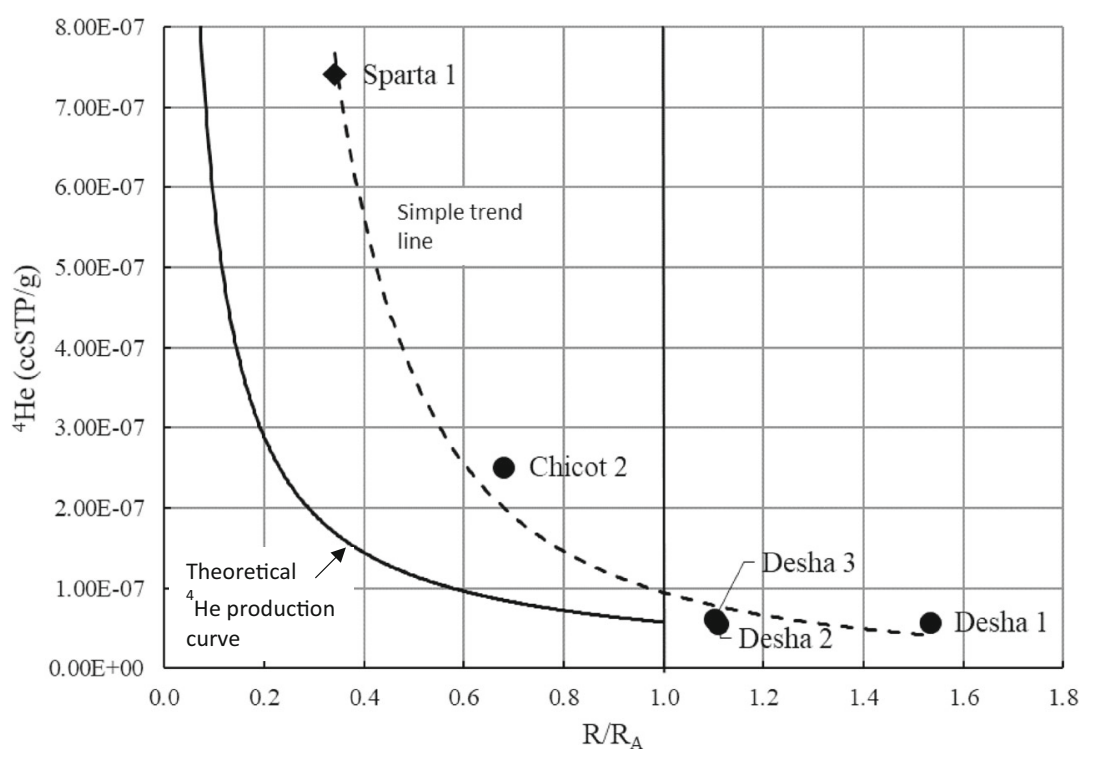

Fig. $11{ }^{4} \mathrm{He}$ concentrations plotted against R/R $\mathrm{R}$ values. A ${ }^{4} \mathrm{He}$ production curve based on Eqs. (1) and (2) (Solomon 2000) as well as the atmospheric $R / R_{a}$ value (Solomon 2000) are added for reference. Site symbols correspond with those in Fig. 1

high-chloride waters, which plot beneath the $\mathrm{Ca}-\mathrm{Br}$ mixing line (Fig. 8), may reflect precipitation of calcite in the MRVA aquifer.

Mixing of only a small percentage of Smackover Formation fluid with other water is needed to create the geochemical trends in the MRVA aquifer water samples. Applying a binary mixing model (Eq. 4) for the most chloride-rich MRVA aquifer water sample (Chicot 3) using the average chloride concentration from Smackover Formation brine (Carpenter and Trout 1978) ( $\left.f_{\text {avg. Smackover }}\right)$ and the relatively fresh Desha 1 water sample concentration $\left(f_{\text {Desha1 }}\right)$, requires less than $1 \%$ of Smackover Formation fluid.

$f_{\text {Chicot3 }}=f_{\text {Desha1 }} / f_{\text {avg.Smackover }}-f_{\text {Desha1 }}$

Thus, several characteristics of the chemical composition of the chloride-rich MRVA water samples are likely due to a small quantity of mixed Smackover Formation fluid.

Although the chemistry of the chloride-rich MRVA aquifer water samples is largely determined by the Smackover Formation fluids, the stable isotope composition is mainly determined by mixing with waters similar to those of the Lower Wilcox Formation and some degree of evaporation. The samples from this study follow a trajectory into the range of stable oxygen and hydrogen isotope values of Lower Wilcox waters in Louisiana (Fig. 9), with sample Chicot 2 plotting within the Lower Wilcox field. Applying a binary mixing model similar to Eq. (4) to evaluate the Lower Wilcox contribution to sample Chicot 3 results in between $13 \%$ $\left(\delta^{18} \mathrm{O}\right)$ and $34 \%\left(\delta^{2} \mathrm{H}\right)$ of Lower Wilcox water, resulting in chloride concentrations 5-15 times higher than those measured (190-500 mmol). Also, sample Chicot 2 cannot be almost entirely composed of a water similar to Lower Wilcox because the chloride concentration of average Lower Wilcox water is two orders of magnitude greater than that measured in sample Chicot 2. A more likely scenario is that some degree of evaporation affects the overall concentration and stable isotope composition of MRVA aquifer waters at some point in their evolution. One possibility is irrigation using chloriderich MRVA aquifer water becomes partially evaporated agricultural runoff that is discharged into canals during the summer and seeps beneath the canal bed into the MRVA aquifer. The agricultural runoff becomes recharge that percolates downward in the MRVA aquifer to mix with older aquifer water and is then pumped to the surface in a subsequent season. This process would not affect the $\mathrm{Cl} / \mathrm{Br}$ ratio or overall $\mathrm{Na}-\mathrm{Cl}$ trend, but would impact the stable isotope composition as summertime evaporation may create a more enhanced evaporative isotopic trend under dry summer, temperate conditions (Putman et al. 2019).

Previous studies have inferred upward flow of saline water from depth into the MRVA aquifer mainly using chemical data. Huff and Bonck (1993) identified a linear trend of high-chloride water in the MRVA aquifer of northeastern Louisiana and used $\mathrm{Br} / \mathrm{Cl}$ ratios to argue for the Smackover Formation being one of the sources. The linear trend identified by Huff and Bonck (1993) continues north to follow the trend observed in SE AR (Area II in Fig. 1). Kresse and Clark (2008) reviewed evidence for upward flow of high-chloride water from depth into the MRVA aquifer and show a similar narrow, NNE-trending distribution in the underlying Upper 
Claiborne aquifer, suggesting upward flow affected salinity in both the MRVA and upper Claiborne aquifers in Chicot County (Area II in Fig. 1). Kresse and Clark (2008) also indicated that the highest chloride concentrations also corresponded to a N-S trend of point-bar deposits in the MRVA (Saucier 1994) and local groundwater mound, suggesting that surficial deposits may also influence the distribution of salinity.

\section{Upward flow of deep basinal fluids into the MRVA aquifer}

Upward flow of deep basinal fluids into the MRVA aquifer requires excess fluid pressure at depth to drive fluids to the surface and the presence of conductive faults as pathways. Excess fluid pressure is evident from flowing artesian conditions in the Lower Claiborne aquifer (Artesian sample). Underlying formations similarly have hydraulic head greater than that of the land surface or are overpressured (Hanor and McIntosh 2007; McIntosh et al. 2010). The Jurassic Smackover Formation is known to have a high pressure gradient $(24.0 \mathrm{kPa} / \mathrm{m})$ for the $\mathrm{ME}$ (Parker 1976), which is indicative of overpressured conditions and conducive to upward flow to the surface. For reference, typical freshwater and saline-water petroleum reservoirs are 9.73 and $11.3 \mathrm{kPa} / \mathrm{m}$, respectively (Spencer 1987). Hanor and McIntosh (2007) argued that upward migration of deep basinal brines into the upper Mesozoic section in Louisiana and Arkansas was not simply diffusive, but, rather, driven by a dynamic process such as that analogous to eddy diffusion in oceanic systems. Given the localized presence of high-chloride waters in the MRVA aquifer and underlying Cenozoic deposits in northern Louisiana and SE AR, Land and Prezbindowski's (1981) model for updip and upfault migration of brine from overpressured zones in the Texas Gulf Coast seems more appropriate, with upward injection during periodic expulsion events.

Numerical modelling of upward brine migration in a multilayered aquifer system suggests that both heat flow and pressure will drive brine upward along fault pathways into overlying aquifers (Delfs et al. 2016). The permeability of the individual aquifers overlying the brine injection site influence not only the brine migration upwards, but also the degree of upward displacement of intermediate aquifer waters. Furthermore, Tillner et al. (2016) numerically modelled similar conditions and showed that maximum vertical migration of brines is achieved when intermediate aquifers are absent or relatively impermeable and fault damage zone volume is relatively small.

SE AR is within a structurally complex area with several intersecting fault zones that may provide pathways for upward flow of deep basinal fluids (Fig. 12). The basement Alabama-Oklahoma transform (AOT) is the most significant tectonic structure that passes through the study area (Fig. 12; Thomas 1991, 2011; Cox et al. 2013). This structure is bound by the Arkansas River Fault Zone (ARFZ) to the north and Saline River Fault Zone (SRFZ) to the south. The ARFZ shows evidence of Quaternary deformation north of the study area (Hao et al. 2015), and the SRFZ shows evidence of Holocene surface rupture west of the study area and Holocene sand-blow development within the study area (Cox et al. 2013). At least one fault in the SRFZ that demonstrates Holocene surface rupture also penetrates the Jurassic section (Cox et al. 2013), which in theory would create a pathway to the shallow subsurface. The eastern margin of the Reelfoot rift extends from the northeast to Chicot County, where most maps show its termination (Thomas 2011; Hao et al. 2015), but Zimmerman (1992) shows extension to the south into northern Louisiana (Z-fault, Fig. 12).

A key aspect of upward brine migration in SE AR is a triggering mechanism to release overpressured fluid from depth to migrate upward through the ME aquifer system to the MRVA aquifer. Although minimal earthquake activity is presently occurring in the southern ME, Cox et al. (2006, 2010, 2012) document evidence of past earthquake activity from surface exposures and liquefaction fields in northeastern Louisiana and SE AR (Fig. 12). These studies indicate three or more significant earthquakes $(\sim \mathrm{M}$ $5.5-7$, depending on assumptions) affected the region between 6,800 and 800 years before present, creating localized liquefaction features in Holocene backswamp and Late Wisconsin terrace deposits (Fig. 12). The geographic correspondence of the liquefaction fields and highchloride waters in the MRVA aquifer is striking (Fig. 12), although the high-chloride groundwater is displaced to the east of the liquefaction fields in northeastern Louisiana. Paul et al. (2017) showed a strong correspondence between sand-blow density and chloride concentrations in the MRVA aquifer in Desha County, suggesting that tectonic influences more strongly affected chloride concentrations than either infiltration through backswamp deposits or from major rivers. Hao et al. (2015) show that faults displacing Quaternary deposits in SE AR extend to at least $1.5 \mathrm{~km}$ beneath the surface (Fig. 12), which Cox et al. (2013) indicate as the approximate depth of the Smackover Formation in SE AR. Thus, Holocene earthquake activity along these faults may have developed a pathway for Smackover Formation brines to migrate upward into overlying aquifers. As Smackover brines migrated into overlying reservoirs or aquifers, they would have displaced the resident fluid upward, similar to that described by numerical modeling 


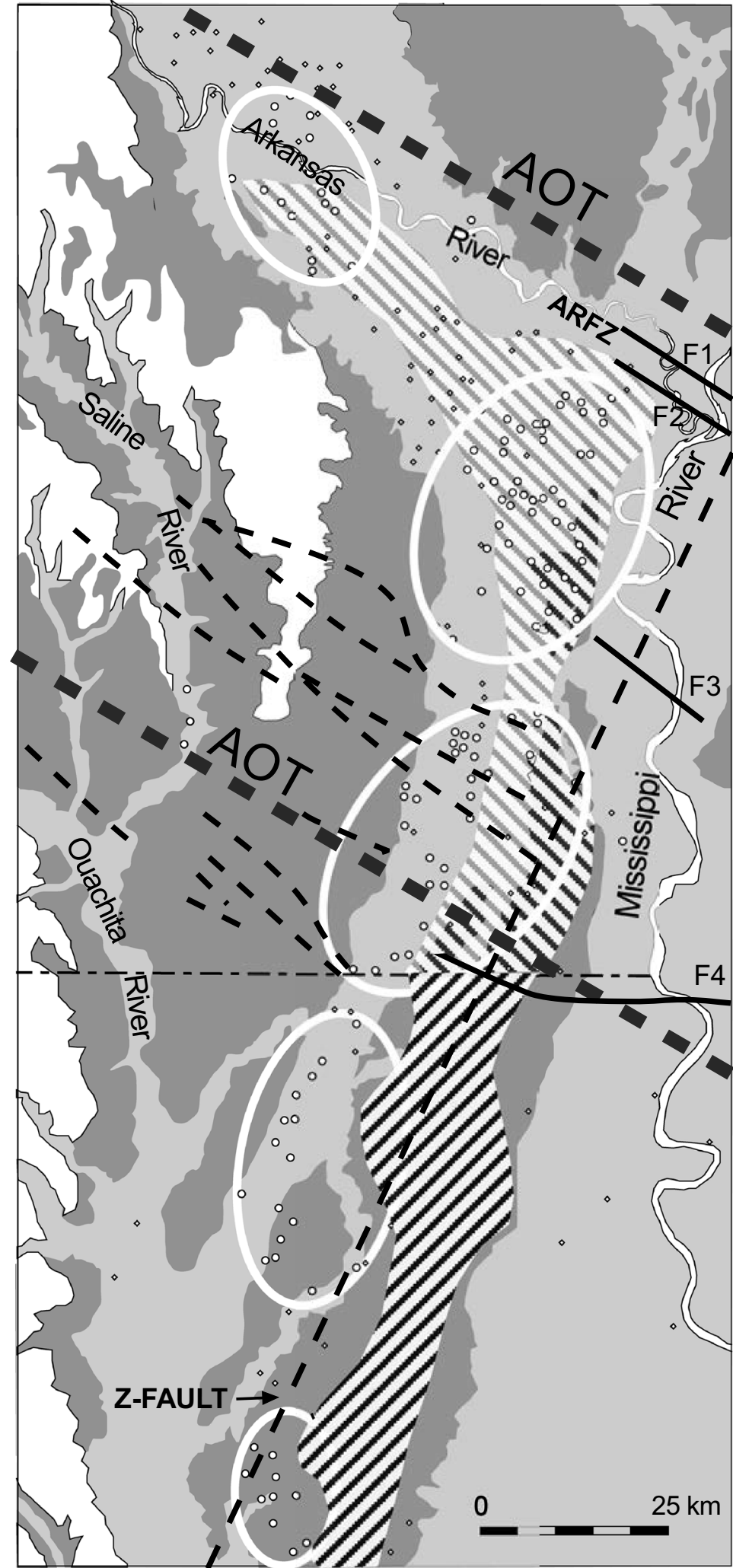

KEY

Holocene Alluvial Deposits

Pleistocene Deposits

Pre-Quaternary Deposits

Earthquake-induced Liquefaction

Fields (Cox et al., 2006; 2010)

Distinct sand blow

O clusters interpreted

from aerial photos

Possible sand blow

$\diamond \quad$ clusters interpreted from aerial photos

MRVA Aquifer Water with $>100 \mathrm{mg} / \mathrm{L}$ Chloride (Kresse and Clark 2008)

MRVA Aquifer Water with $>100 \mathrm{mg} / \mathrm{L}$ Chloride (Huff and Bonck 1993)

\section{Arkansas-Oklahoma}

Transform Zone (Hao et al.

2015, after Thomas 1991)

Z-FAULT, NE-trending

Wrench Fault (Zimmerman

1992)

- Subsurface Faults (Cox et al.

$\checkmark$ 2013)

Subsurface Faults - numbered (Hao et al. 2015)

$33^{\circ} 00^{\prime} 00^{\prime \prime} \mathrm{N}$

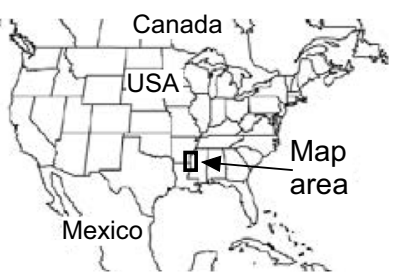

Fig. 12 Map of the study area and northeastern Louisiana showing distribution of earthquake-induced sand blow fields, zones of high chloride contents ( $>100 \mathrm{mg} / \mathrm{L}$ chloride), and regional structural features.
Quaternary geologic map units, from Saucier (1994) and references therein. ARFZ Arkansas River fault zone 


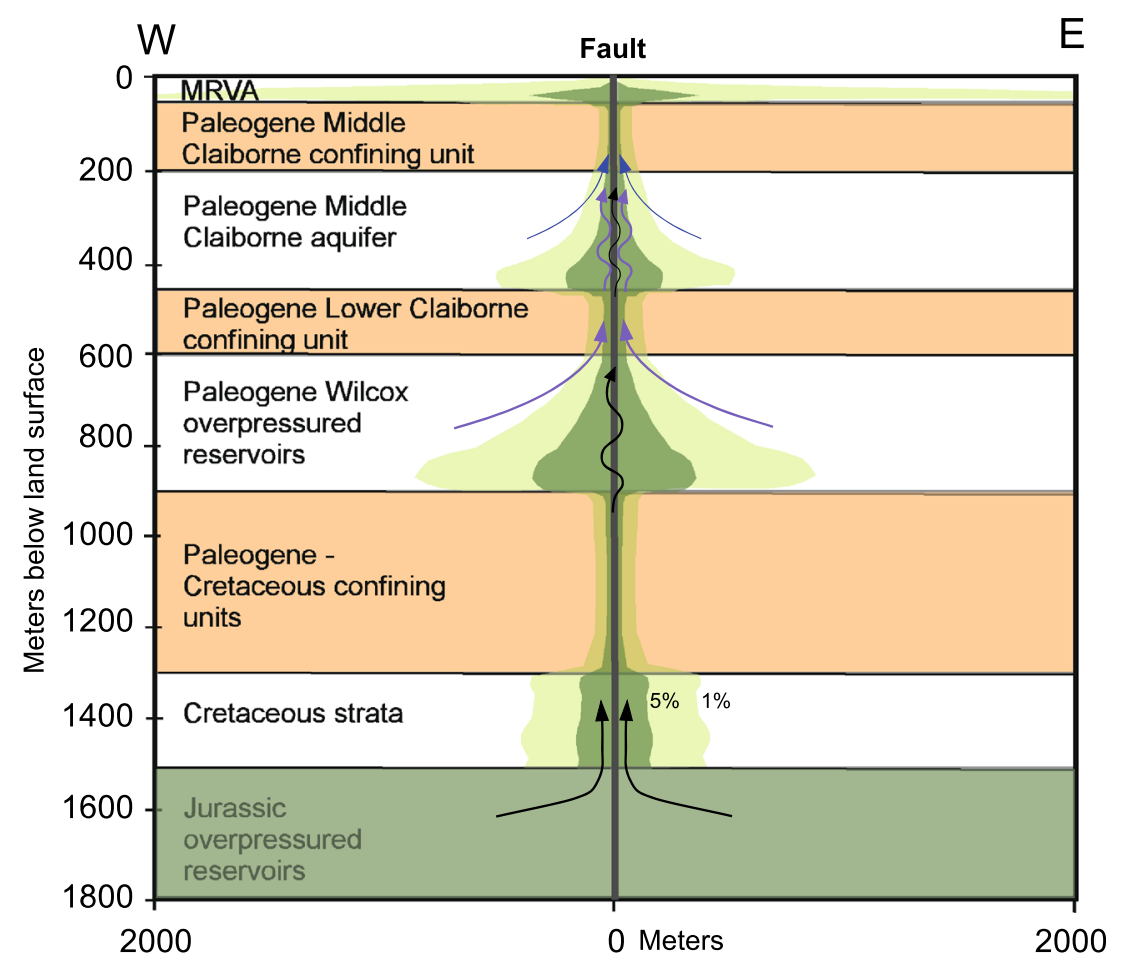

Fig. 13 Conceptual model of upward brine migration from the Jurassic Smackover Formation (Jurassic overpressured reservoir) along a fault to overlying reservoirs and aquifers in SE AR. The depth and brine percentages are similar to those modeled numerically by Delfs et al. (2016) in the North German Basin. Lighter shades of green above Jurassic reservoir represent 5\% and 1\% Smackover Formation brine. Stratigraphy and depth in SE AR are simplified from Cox et al. (2013)

studies (Fig. 13; Delfs et al. 2016; Tillner et al. 2016). Displacement of the resident fluid is dependent upon hydraulic conductivity and fluid pressure within a given hydrostratigraphic interval; thus, displacement is greatest in prominent aquifers with lower fluid pressures. The predominance of Wilcox and probably some Claiborne aquifer water along with a trace quantity of Smackover Formation brine in the MRVA aquifer adjacent to the affected faults is predicted by the modeling results (Fig. 13). The rate of upward migration of brine is difficult to assess, but if overpressure and fault pathways persist, fluids may continue upward migration for 100 s to 1,000 s of years based on the numerical studies (Delfs et al. 2016; Tillner et al. 2016). Considering these results, the lack of temporal variation in chloride content of affected wells in the MRVA in SE AR during the past 75 years (Kresse and Clark 2008) is expected. Furthermore, upward migration of hot, saline fluids may contribute to the regional heat flow anomaly in SE AR and extending northwestward along the Arkansas River valley (Blackwell et al. 2006).

Continued extraction of water from the MRVA aquifer for irrigation in SE AR is likely to exacerbate the extent of high-chloride conditions by lowering head in the and Hao et al. (2015). Black arrows represent Smackover Formation brine, purple arrows Wilcox pore fluids, and blue arrows Middle Claiborne water. Arrow line weight corresponds to prominence in mixing. MRVA is the MRVA aquifer. Extent of lateral migration based on aquifer (reservoir) characteristics in Clark et al. (2011) and Waldron et al. (2011)

aquifer and potentially inducing infiltration of agricultural runoff. As of 2010 , metered water use from the MRVA in Chicot and Desha counties was approximately 2 billion L/day, which, assuming $30 \%$ porosity, equates to $\sim 2 \mathrm{~mm}$ of decline across the two counties. Water table decline in the two counties since 1977 ranges from 0.08 to $0.2 \mathrm{~m} /$ year, with a maximum of $9 \mathrm{~m}$ of decline in the water table within Desha County from 1960 to 2012 Kresse et al. (2014). Two cones of depression in the potentiometric surface of the MRVA aquifer in Desha County (Schrader 2006) roughly correspond to the extent of high-chloride waters (Fig. 1). The degree of groundwater use increases potential for recharge by creating a lowered hydraulic head relative to surrounding areas. Given that the extent of high-chloride waters in the MRVA aquifer has not changed (Kresse et al. 2014), the continual extraction of water from the aquifer requires that the high-chloride water be replenished by some combination of upward flow of high-chloride water along faults and downward percolation of high-chloride agricultural runoff from canals. The results from the present study suggest that both of these processes may be important, but further sampling and analysis are required to elucidate the extent. 
The results from the present study in the Mississippi embayment suggest that upward pore fluid migration into shallow aquifers can be induced by seismicity when specific conditions are met: (1) overpressured porefluids at depth, (2) fault movement that abruptly creates permeable pathways for overpressured fluids to migrate to the surface, and (3) porous and permeable aquifer strata in hydraulic communications with the fault zone (Delfs et al. 2016; Rosen et al. 2018). Of critical importance are the properties of the fault zone (Bense et al. 2017; Tillner et al. 2016); however, an important consideration is also the regional hydrogeology of the aquifer system. In the case of the southern ME, a sedimentary basin with groundwater flow focused toward the north-south centerline of the basin, the conditions may be ideal for earthquake-induced upward flow of deep fluids into the shallow subsurface. The close association of seismic activity and upward flow of saline fluids argues for concern in similar seismically active sedimentary basins with shallow groundwater resources vulnerable to salinization. The results of the current study also provide needed field data to assess the geologic conditions under which upward flow of deep pore fluids, whether naturally present or anthropogenically injected, may be released by seismic activity into shallow aquifer systems. Clarification of the seismic energy release, pore-pressure conditions, and fault properties leading to upward flow of pore fluids need to be further addressed to understand the vulnerability of shallow groundwater resources in these settings (e.g., Meyers 2012; Flewelling et al. 2013).

\section{Conclusions}

The MRVA aquifer in SE AR is used extensively for agricultural irrigation, but is known to have areas of anomalously high salinity that limit agricultural use. This study used existing water chemistry data from wells in the MRVA aquifer in SE AR to identify a limited number of wells to sample for chemical and isotopic tracers to determine the source of saline waters, as evident by anomalously high $(>100 \mathrm{mg} / \mathrm{L})$ chloride contents. Additional wells in the Middle and Lower Claiborne aquifers were also sampled for comparison. Principal component analysis of the available chemical data for both the MRVA and Middle Claiborne aquifers resulted in two main factors, one representing relatively fresh groundwater and a second representing water affected by increased salinity. Wells selected for sampling from the MRVA in Desha and Chicot counties, Arkansas, represent the spectrum of salinity observed in the region. The Middle Claiborne wells sampled were both relatively freshwater and the Lower Claiborne well was a flowing artesian well.
The water chemistry of the sampled MRVA wells have anomalously low $\mathrm{Cl} / \mathrm{Br}$ ratios that best fit a salinity source from the Jurassic Smackover Formation, which is approximately $1.5 \mathrm{~km}$ below the land surface. Calcium, lithium, and strontium correlation with bromide as well as the $\mathrm{Na} /$ $\mathrm{Cl}$ ratio of the sampled MRVA aquifer wells also support a Smackover Formation source. Stable hydrogen and oxygen isotope data favor mixing with a source water similar to that of the Wilcox Formation in Louisiana, with some modification by surface evaporation. Limited carbon-14 age data correlate with chloride concentrations, indicating that chloride is sourced from older fluids. Similarly, lower tritium, higher helium, and lower $\mathrm{R} / \mathrm{R}_{\mathrm{a}}$ correspond with higher chloride concentrations in the MRVA aquifer groundwater. Comparison of the ensemble tracer data with water chemistry and isotope composition of likely salinity sources indicate the presence of less than $1 \%$ Smackover Formation fluid in the most saline MRVA groundwater, with a significant proportion of the water originating from a Wilcox Formation-like basinal source. An additional source of salinity is likely evaporative concentration of saline groundwater from infiltration of summer agricultural runoff in the region.

The introduction of deep basinal fluids into the MRVA aquifer is conceptually modeled to have occurred by upward flow along regional faults. The Smackover Formation is overpressured, as are other petroleum reservoir units in the region, providing a driving mechanism for upward flow. Furthermore, numerical modeling of brine migration along faults in other sedimentary basins (Delfs et al. 2016; Tillner et al. 2016) indicates that fluids from shallower overpressured reservoirs would be displaced upward along the fault as the deep brine ascends. The resulting fluid mixture in the shallow aquifer would have a small fraction of deep basin brine with larger fractions of shallower displaced fluids, consistent with the mixing fractions of Smackover and Wilcox formation fluids in the MRVA groundwater.

The triggering mechanism for upward flow is argued to be Holocene earthquake movement along regional faults, which is evident from earthquake liquefaction features. The liquefaction features show a strong co-location with the high-chloride groundwater in the MRVA aquifer in SE AR and northeastern Louisiana. At least three major earthquakes are documented in the region, dating from 6,800 to 800 years BP (Cox et al. 2010). These earthquakes are argued to have created a continuous fracture system from the Smackover Formation to the MRVA, creating pathways for upward fluid movement. Based on numerical modeling in other sedimentary basins (Delfs et al. 2016; Tillner et al. 2016), persistent overpressure and open fault pathways would allow upward fluid flow for 100 s to 1,000 s of years. The current spatial and temporal pattern of high-chloride waters in the MRVA aquifer in SE 
AR is consistent with continued upward migration of the deep basinal fluids, perhaps exacerbated by continued agricultural extraction and infiltration of evaporatively concentrated saline agricultural runoff.

The conceptual model for anomalously high salinity in MRVA aquifer groundwater provides evidence that under specific conditions earthquakes result in the upward migration of deep basinal fluids into shallow groundwater reservoirs. Numerous studies have shown changes in shallow groundwater chemistry immediately following earthquake events (Malakootian and Nouri 2010; Skelton et al. 2014; Rosen et al. 2018), but most of these studies suggest that the short-term water chemistry changes are related to release of pore fluids during earthquake-related dilation or changes in near fault hydrologic characteristics (Rosen et al. 2018). In at least one case, water chemistry changes following in earthquake indicate the rise of deep-seated fluids (Barberio et al. 2017). Despite these observations, numerous studies have shown evidence for upward migration of deep basin fluids and brines along faults to shallow aquifers and surface waters (Druhan et al. 2008; Petitta et al. 2011; Keating et al. 2013), suggesting that earthquakes may create pathways along faults for upward fluid movement from depth. The results from the current study provide a link between past earthquake activity and current water quality conditions indicating that earthquake activity may induce upward migration of deep basinal fluids, especially where overpressured fluids exist at depth. The results also have implications for conditions under which induced seismicity may lead to upward flow of deep basinal fluids, whether natural or injected, along faults.

Acknowledgements Thanks are extended to Erik Pollock and Philip Hayes at the University of Arkansas Stable Isotope Lab for assisting with the stable isotope measurements and Gregg Davidson at the University of Mississippi Geology and Geological Engineering Department for trace element analysis. Katherine Knierum graciously provided stable isotope data for the MRVA aquifer from recent United States Geological Survey, (USGS) studies. Tim Kresse provided access to USGS and State of Arkansas water chemistry data for southeastern Arkansas and provided guidance in interpreting the data. Much appreciation is extended to the Chicot and Desha County National Resources Conservation Service offices for their help in contacting well operators, in addition to the various well operators for giving access to their wells. The manuscript was greatly improved by thoughtful review comments from associate editor Sebnem Arslan, reviewer Mahmoud Sherif, and an anonymous reviewer.

Funding information Special thanks to the Geological Society of America, Southeastern Section, for partially funding of this project.

Open Access This article is licensed under a Creative Commons Attribution 4.0 International License, which permits use, sharing, adaptation, distribution and reproduction in any medium or format, as long as you give appropriate credit to the original author(s) and the source, provide a link to the Creative Commons licence, and indicate if changes were made. The images or other third party material in this article are included in the article's Creative Commons licence, unless indicated otherwise in a credit line to the material. If material is not included in the article's Creative Commons licence and your intended use is not permitted by statutory regulation or exceeds the permitted use, you will need to obtain permission directly from the copyright holder. To view a copy of this licence, visit http://creativecommons.org/licenses/by/4.0/.

\section{References}

Ackerman DJ (1996) Hydrology of the mississippi river valley alluvial aquifer, South-Central United States. US Geol Surv Prof Pap 1416D, pp 68

Aeschbach-Hertig W, Peeters F, Beyerle U, Kipfer R (2000) Paleotemperature reconstruction from noble gases in ground water taking into account equilibration with entrapped air. Nature 405: $1040-1044$

Alhassan M, Lawrence CB, Richardson S, Pindilli EJ (2019) The Mississippi Alluvial Plain Aquifers: an engine for economic activity. US Geol Surv Fact Sheet 2019-3003. http://pubs.er.usgs.gov/ publication/fs20193003. Accessed 18 Mar 2019

Barberio MD, Barbieri M, Billi A, Doglioni C, Petitta M (2017) Hydrogeochemical changes before and during the 2016 AmatriceNorcia seismic sequence (central Italy). Sci Rep 7(1):11735. https:// doi.org/10.1038/s41598-017-11990-8

Bedinger MS, Jeffery HG, (1964) Ground water in the lower arkansas river valley, arkansas. US Geol Surv Water Suppl Pap 1669 , pp 17

Bedinger MS, Reed JE (1961) Geology and groundwater resources of desha and lincoln counties, Arkansas. Arkansas Geol Conserv Comm Water Resour Circ 6, pp 129

Bense VF, Gleeson T, Loveless SE, Bour O, Scibek J (2017) Fault zone hydrogeology. Earth-Sci Rev 127:171-192. https://doi.org/10.1016/ j.earscirev.2013.09.008

Blackwell DD, Negraru PT, Richards MC (2006) Assessment of the enhanced geothermal system resource base of the United States. Nat Resour Res 15:283-308. https://doi.org/10.1007/s11053-0079028-7

Blackwell DD, Richards MC, Frone ZS, Batir JF, Williams MA, Ruzo AA, Dingwall RK (2011) SMU Geothermal Laboratory heat flow map of the conterminous United States. http://www.smu.edu/ geothermal. Accessed 10 September 2015

Broom ME, Reed JE (1973) Hydrology of the bayou bartholomew alluvial aquifer-stream system, Arkansas. US Geol Surv Open-File Rep 73-34, pp 91

Carpenter AB, Trout ML (1978) Geochemistry of bromide-rich brines of the Dead Sea and southern Arkansas, Oklahoma. US Geol Surv Circ 79:78-88

Carrillo-Rivera JJ, Cardona A, Moss D (1996) Importance of the vertical component of groundwater flow: a hydrogeochemical approach in the valley of San Luis Potosi, Mexico. J Hydrol 185:23-44. https:// doi.org/10.1016/S0022-1694(96)03014-4

Cherry GS (2019) Simulation of groundwater flow in the brunswick area, Georgia, for 2004 and 2015, and selected groundwater-management scenarios. US Geol Surv Sci Invest Rep 2019-5035, pp 70. https:// doi.org/10.3133/sir20195035

Claesson L, Skelton A, Graham C, Dietl C, Mörth M, Torssander P, Kockum I (2004) Hydrogeochemical changes before and after a major earthquake. Geology 32(8):641-644. https://doi.org/10. 1130/G20542.1 
Clark BR, Hart RM, Gurdak JJ (2011) Groundwater availability of the Mississippi embayment. US Geol Surv Prof Paper 1785, pp 62

Clarke WB, Jenkins WJ, Top Z (1976) Determination of tritium by mass spectrometric measurements of ${ }^{3} \mathrm{He}$. Int J Appl Radioactive Isotopes 27:515-522

Cook P, Bohlke JK (2000) Determining timescales for groundwater flow and solute transport. In: Cook P, Herczeg A (eds) Environmental tracers in subsurface hydrology. Kluwer, Boston, pp 1-30

Cook PG, Dogramaci S (2019) Estimating recharge from recirculated groundwater with dissolved gases: an end-member mixing analysis. Water Resour Res 55(7):5468-5486. https://doi.org/10.1029/ 2019WR025012

Coplen T, Herczeg A, Barnes C (2000) Isotope engineering using stable isotopes of the water molecule to solve practical problems. In: Cook P, Herczeg A (eds) Environmental tracers in subsurface hydrology. Kluwer, Boston, pp 79-110

Cox RT, Van Arsdale R (2002) The Mississippi embayment, North America: a first order continental structure generated by the cretaceous superplume mantle event. J Geodynam 34:163-176

Cox RT, Larsen D, Forman SL, Woods J, Morat J (2004) Preliminary assessment of sand blows in the southern Mississippi embayment. Bull Seismolog Soc Am 94:1125-1142

Cox RT, Hill AA, Larsen D, Holzer T, Forman SL, Noce T, Gardner C, Morat J (2006) Seismotectonic implication of sand blows in the southern Mississippi Embayment. Eng Geol 89(3):278-299. https://doi.org/10.1016/j.enggeo.2006.11.002

Cox RT, Gordon J, Forman S, Brezina T, Negrau M, Hill AA, Gardner C, Machin S (2010) Paleoseismic sand blows in North Louisiana \& South Arkansas. Seismol Res Lett 81:1032-1047

Cox RT, Harris J, Forman S, Brezina T, Gordon J, Gardner C, Machin S (2012) Holocene faulting on the Saline River fault zone, Arkansas, along the Alabama-Oklahoma transform. In: Cox RT, Tuttle MP, Boyd OS, Locat J (eds) Recent Advances in North American Paleoseismology and Neotectonics East of the Rockies. Geol Soc Am Spec Pap 493. Boulder, USA, pp 143-164. https://doi.org/10. 1130/2012.2493(07)

Cox RT, Hall JL, Gardner CS (2013) Tectonic history and setting of a seismogenic intraplate fault system that lacks microseismicity: the Saline River fault system, southern United States. Tectonophysics 608:252-266. https://doi.org/10.1016/j.tecto.2013.09.031

Craig H (1961) Isotopic variations in meteoric waters. Science 133:17021703. https://doi.org/10.1126/science.133.3465.1702

Cushing EM, Boswell EH, Hosman RL (1964) General geology of the Mississippi embayment. US Geol Surv Prof Pap 448-B, pp 28

Czarnecki JB (2010) Groundwater-flow assessment of the Mississippi River alluvial aquifer of northeastern Arkansas. US Geol Surv Sci Invest Rep 2010-5210, pp 33

Deines P (1980) The isotopic composition of reduced organic carbon. In: Fritz P, Fontes JC (eds) Handbook of environmental isotope geochemistry 1. Elsevier, Amsterdam, pp 329-406

Delfs J, Nordbeck J, Bauer S (2016) Upward brine migration resulting from pressure increases in a layered subsurface system. Environ Earth Sci 75:1441. https://doi.org/10.1007/s12665-016-6245-6

Dickinson KA (1968) Upper Jurassic stratigraphy of some adjacent parts of Texas, Louisiana, and Arkansas. US Geol Surv Prof Pap 594-E, pp 25

Druhan JL, Hogan JF, Eastoe CJ, Hibbs BJ, Hutchinson WR (2008) Hydrogeologic controls on groundwater recharge and salinization: a geochemical analysis of the northern Hueco bolson aquifer, Texas, USA. Hydrogeol J 16:281-296. https://doi.org/10.1007/s10040007-0222-9

Eppelbaum L, Kutasov I, Pilchin A (2014) Applied Geothermics, lecture notes in earth system sciences. Springer, Heidelberg, Germany. https://doi.org/10.1007/978-3-642-34023-9-2

Evans DG, Nunn JA, Hanor JS (1991) Mechanisms driving groundwater flow near salt domes. Geophys Res Lett 18(5):927-930
Favara R, Italiano F, Martinelli G (2001) Earthquake-induced chemical changes in the thermal waters of the Umbria region during the 19971998 seismic swarm. Terra Nova 13(3):227-233. https://doi.org/10. 1046/j.1365-3121.2001.00347.x

Fetter CW (2001) Applied hydrogeology, 4th edn. Prentice Hall, Englewood Cliffs, NJ, pp 691

Fitzpatrick DJ (1985) Occurrence of saltwater in the alluvial aquifer in the Boeuf-Tensas Basin, Arkansas. US Geol Surv Water Resour Invest Rep 85-4029, 1 sheet

Flewelling SA, Timchak MP, Warpinski N (2013) Hydraulic fracture height limits and fault interactions in tight oil and gas formations. Geophys Res Lett 40:3602-3606. https://doi.org/10.1002/grl.50707

Frumkin A, Gvirtzman H (2006) Cross-formational rising groundwater at an artesian karstic basin: the Ayalon saline anomaly, Israel. J Hydrol 318(1-4):316-333. https://doi.org/10.1016/j.jhydrol.2005.06.026

Gardner PM, Heilweil VM (2014) A multiple tracer approach to understanding regional ground water flow in the Snake Valley area of the eastern Great Basin, USA. Appl Geochem 45:33-49. https://doi.org/ 10.1016/j.apgeochem.2014.02.010

Haile E (2011) Chemical evolution and residence time of groundwater in the Wilcox aquifer of the northern Gulf Coastal Plain. PhD Thesis, Earth and Environmental Sciences, University of Kentucky, Lexington, KY, pp 108

Hanor JS (1987) Origin and migration of subsurface sedimentary brines. SEPM lecture notes for short course, 21. Society for Sedimentary Geology, Tulsa, OK

Hanor JS, McIntosh JC (2007) Diverse origins and timing of formation of basinal brines in the Gulf of Mexico sedimentary basin. Geofluids 7: 227-237

Harry DL, Londono J (2004) Structure and evolution of the Central Gulf of Mexico continental margin and coastal plain, Southeast United States. Geol Soc Am Bull 116:188-199

Hart RM, Clark BR, Bolyard SE (2008) Digital surfaces and thicknesses of selected hydrogeologic units within the Mississippi Embayment Regional Aquifer Study (MERAS). US Geol Surv Sci Invest Rep 2008-5098, pp 33

Hao Y, McIntosh K, Magnani MB (2015) Long-lived deformation in the southern Mississippi embayment revealed by high-resolution seismic reflection and sub-bottom profiler data. Tectonics 34:555-570. https://doi.org/10.1002/2014TC003750

Howard KWF, Mullings E (1996) Hydrochemical analysis of groundwater flow and saline incursion in the Clarendon Basin, Jamaica. Ground Water 34(5):801-810

Huff GF, Bonck JP (1993) Saltwater in shallow aquifers in east-central and northeastern Louisiana and southeastern Arkansas. US Geol Surv Open File Rep 93-494

Kalin R (2000) Radiocarbon dating of groundwater systems. In: Cook P, Herczeg A (eds) Environmental tracers in subsurface hydrology. Kluwer, Boston, pp 111-144

Keating EH, Newell DL, Viswanathan H, Carey JW, Zyvoloski G, Pawar $\mathrm{R}$ (2013) $\mathrm{CO}_{2}$ /brine transport into shallow aquifers along fault zones. Environ Sci Technol 47:290-297. https://doi.org/10.1021/ es301495x

Kendall C, Coplen TB (2001) Distribution of oxygen-18 and deuterium in river waters across the United States. Hydrol Process 15:13631393. https://doi.org/10.1002/hyp. 217

Kendall C, Doctor DH (2005) Stable isotope applications in hydrologic studies. In: Drever J (ed) Surface and ground water, weathering, and soils, treatise on geochemistry. Elsevier-Pergamon, Oxford, pp 319 364

Kingsbury JA, Barlow JR, Katz BG, Welch HL, Tollett RW, Fahlquist LS (2015) The quality of our nation's waters: water quality in the Mississippi Embayment-Texas Coastal Uplands Aquifer System and Mississippi River Valley Alluvial Aquifer, south-central United States, 1994-2008. US Geol Surv Circ 1356. https://pubs. usgs.gov/circ/1356/. Accessed March 2021 
Kreamer DK, Hodge VF, Rabinowitz I, Johannesson KH, Stetzenbach KJ (1996) Trace element geochemistry in water from selected springs in Death Valley National Park, California. Ground Water 35:95-103. https://doi.org/10.1111/j.1745-6584.1996.tb01869.x

Kresse TM, Clark BR (2008) Occurrence, distribution, sources, and trends of elevated chloride concentrations in the Mississippi River Valley alluvial aquifer in southeastern Arkansas. US Geol Surv Sci Invest Rep 5193, pp 34

Kresse TM, Fazio JA (2002) Pesticides, water quality, and geochemical evolution of groundwater in the alluvial aquifer, Bayou Bartholomew, Arkansas. Arkansas Department of Environmental Quality, Water Quality Rep WQ02-051, pp 111

Kresse TM, Hays PD, Merriman-Hoehne KR, Gillip JA, Fugitt DT, Spellman JL, Nottmeier AM, Westerman DA, Blackstock JM, Battreal JL (2014) Aquifers of Arkansas: protection, management, and hydrologic and geochemical characteristics of groundwater resources in Arkansas. US Geol Surv Sci Invest Rep 2014-5149. https://pubs.er.usgs.gov/publication/sir20145149. Accessed March 2021

Kulongoski JT, Hilton DR (2011) Applications of groundwater helium, In Baskaran M (Ed) Handbook of environmental isotope geochemistry, chap 15. Advances in Isotope Geochemistry, 285-303. https:// doi.org/10.1007/978-3-642-10637-8 15

Land LS, Prezbindowski DR (1981) The origin and evolution of saline formation water, lower cretaceous carbonates, southcentral Texas, U.S.A. J Hydrol 54:51-74

Ma L, Castro MC, Hall CM, Walter LM (2005) Cross-formational flow and salinity sources inferred from a combined study of helium concentrations, isotopic ratios, and major elements in the Marshall aquifer, southern Michigan. Geochem Geophys Geosyst 6:Q10004. https://doi.org/10.1029/2005GC001010

Magri F, Bayer U, Pekdeger A, Otto R, Thomsen C, Maiwald U (2009) Salty groundwater flow in the shallow and deep aquifer systems of the Schleswig-Holstein area (north German Basin). Tectonophysics 470(1-2):183-194. https://doi.org/10.1016/j.tecto.2008.04.019

Malakootian M, Nouri J (2010) Chemical variations of ground water affected by the earthquake in Bam region. Int J Environ Res 4(3): 443-454

Mazor E (1976) Multi-tracing and multisampling in hydrological studies. In: Interpretation of environmental isotope and hydro-chemical data in groundwater hydrology. IAEA, Vienna, pp 7-36

McCaffrey MA, Lazar B, Holland HD (1987) The evaporation path of seawater and the coprecipitation of $\mathrm{Br}$ and $\mathrm{K}$ with halite. J Sediment Petrol 57:928-937

McIntosh JC, Warwick PD, Martini AM, Osborn SG (2010) Coupled hydrology and biogeochemistry of Paleocene-Eocene coal beds, northern Gulf of Mexico. Geol Soc Am Bull 122(7-8):1248-1264

McMahon PB, Plummer LN, Boehlke JK, Shapiro SD, Hinkle SR (2011) A comparison of recharge rates in aquifers of the United States based on groundwater-age data. Hydrogeol J 19(4):779-800. https://doi.org/10.1007/s10040-011-0722-5

Mehta S, Fryar AE, Brady RM, Morin RH (2000) Modeling regional salinization of the Ogallala aquifer, southern High Plains, TX, USA. J Hydrol 238(1-2):44-64. https://doi.org/10.1016/S00221694(00)00314-0

Meyers T (2012) Potential contaminant pathways from hydraulically fractured shale to aquifers. Ground Water 50(6):872-882. https:// doi.org/10.1111/j.1745-6584.2012.00933.x

Moldovanyi EP, Walter LM (1993) Regional trends in water chemistry, Smackover Formation, Southwest Arkansas: geochemical and physical controls. Am Assoc Petroleum Geol Bull 76(6):864-894

NOSAMS (2015) Woods Hole Oceanographic Institution homepage. https://www.whoi.edu/nosams/home. Accessed July 2015

Onellion FE, Criner JH (1955) Groundwater resources of Chicot County, Arkansas. Water Resour Circ 3, Arkansas Geology and Conservation Commission, Little Rock, AR, pp 27
Palcsu L, Kompar L, Deak J, Szucs P, Papp L (2017) Estimation of the natural groundwater recharge using tritium-peak and tritium/helium3 dating techniques in Hungary. Geochem J 51(5):439-448. https:// doi.org/10.2343/geochemj.2.0488

Parker CA (1976) Geopressures and secondary porosity in deep Smackover of Mississippi. Am Assoc Petroleum Geol Bull 60(4): 705

Parkhurst DL, Appelo CAJ (1999) User's Guide to PHREEQC (version 2): a computer program for speciation, batch-reaction, onedimensional transport, and inverse geochemical calculations. US Geol Surv Water Resour Invest Rep 99-4259, pp 327

Paul JM (2015) The source of saline groundwater in the Mississippi River Valley Alluvial aquifer in southeastern Arkansas. MSc Thesis, University of Memphis, Memphis, TN, pp 92

Paul JM, Larsen D, Cox R (2017) The spatial statistical relationship between geomorphic soils, tectonic features, and chloride anomalies in the Mississippi River valley alluvial aquifer in Southeast Missouri. Groundw Sustain Develop 6:101-111. https://doi.org/10. 1016/j.gsd.2017.11.005

Petitta M, Primavera P, Tuccimei P, Aravena R (2011) Interaction between deep and shallow groundwater in areas affected by quaternary tectonics (central Italy): a geochemical and isotope approach. Environ Earth Sci 63:11-30. https://doi.org/10.1007/s12665-0100663-7

Putman AL, Fiorella RP, Bowen GJ, Zhongyin C (2019) A global perspective on local meteoric water lines; meta-analytic insight into fundamental controls and practical constraint. Water Resour Res 55(8):6896-6910. https://doi.org/10.1029/2019WR025181

Rosen MR, Binda G, Archer C, Pozzi A, Michetti AM, Noble PJ (2018) Mechanisms of earthquake-induced chemical and fluid transport to carbonate groundwater springs after earthquakes. Water Resources Res 54:5225-5244. https://doi.org/10.1029/2017WR022097

Saucier RT (1994) Geomorphology and quaternary geologic history of the lower Mississippi River valley, volume I. US Army Corps of Engineers, Waterways Experiment Station, Vicksburg, MS

Schrader TP (2006) Status of water levels and selected water-quality conditions in the Mississippi River Valley alluvial aquifer in eastern Arkansas, 2004. US Geol Surv Water Resour Invest Rep 06-5128, pp 54

Skelton A, Andrén M, Kristmannsdóttir H, Stockmann G, Mörth CM, Sveinbjörnsdóttir Á, Jónsson S, Sturkell E, Guŏrúnardóttir HR, Hjartarson H, Siegmund H, Kockum I (2014) Changes in groundwater chemistry before two consecutive earthquakes in Iceland. Nat Geosci 7(10):752-756. https://doi.org/10.1038/ngeo2250

Solomon K (2000) Helium-4 in groundwater. In: Cook P, Herczeg A (eds) Environmental tracers in subsurface hydrology. Kluwer, Boston, pp 425-440

Solomon DK, Cook PG (2000) ${ }^{3} \mathrm{H}$ and ${ }^{3} \mathrm{H}$. In: Cook P, Herczeg A (eds) Environmental tracers in subsurface hydrology. Kluwer, Boston, pp $397-424$

Spencer CW (1987) Hydrocarbon generation as a mechanism for overpressuring in Rocky Mountain region. Am Assoc Petrol Geol Bull 71(4):368-388

Tacker P, Langston J, Ferguson J, Vories E (1994) Water management: rice production handbook. University of Arkansas Cooperative Extension Service MP, Little Rock, AR

Thomas WA (1991) The Appalachian-Ouachita rifted margin of southeastern North America. Geol Soc Am Bull 103:415-431

Thomas WA (2011) The Iapetan rifted margin of southern Laurentia. Geosphere 7:97-120

Tillner E, Langer M, Kempka T, Kühn M (2016) Fault damage zone volume and initial salinity distribution determine intensity of shallow aquifer salinisation in subsurface storage. Hydrol Earth Syst Sci 20:1049-1067. https://doi.org/10.5194/hess-20-1049-2016

USGS NWIS (2014) Water quality samples for the nation. https://nwis. waterdata.usgs.gov/usa/nwis/qwdata. Accessed 1 July 2014 
USGS NWIS (2015). https://nwis.waterdata.usgs.gov/usa/nwis/qwdata. Accessed 1 Aug 2015

USGS NWIS (2020) Water quality samples for the nation. https://nwis. waterdata.usgs.gov/usa/nwis/qwdata. Accessed 13 May 2020

Vautour G, Pinti DL, Mejean P, Saby M, Meyzonnat G, Larocque M, Castro MC, Hall CM, Boucher C, Roulleau E, Barbecot F, Takahata N, Sano Y $(2015){ }^{3} \mathrm{H} /{ }^{3} \mathrm{He},{ }^{14} \mathrm{C}$ and (U-Th)/he ground water ages in the St. Lawrence Lowlands, Quebec, eastern Canada. Chem Geol 413:94-106. https://doi.org/10. 1016/j.chemgeo.2015.08.003

Waldron B, Larsen D, Hannigan R, Csontos R, Anderson J, Dowling C, Bouldin J (2011) Mississippi embayment regional ground water study, EPA 600/R-10/130, US Environmental Protection Agency, Washington, DC, pp 174
Woith H, Wang R, Maiwald U, Pekdeger A, Zschau J (2013) On the origin of geochemical anomalies in groundwaters induced by the Adana 1998 earthquake. Chem Geol 339:177-186. https://doi.org/ 10.1016/j.chemgeo.2012.10.012

Zhong C, Yang Q, Ma H, Bian J, Zhang S, Lu X (2019) Application of environmental isotopes to identify recharge source, age, and renewability of phreatic water in Yinchuan Basin. Hydrol Process 33(16): 2166-2173. https://doi.org/10.1002/hyp.13468

Zimmerman RK (1992) Fractured Smackover limestone in northeast Louisiana: implications for hydrocarbon exploitation. Gulf Coast Assoc Geol Soc Trans 42:401-412

Publisher's note Springer Nature remains neutral with regard to jurisdictional claims in published maps and institutional affiliations. 